\title{
Estimation of nitrogen budgets for contrasting catchments at the landscape scale
}

\author{
E. Vogt ${ }^{1,2,3}$, C. F. Braban ${ }^{1}$, U. Dragosits ${ }^{1}$, M. R. Theobald ${ }^{1,4}$, M. F. Billett ${ }^{1}$, A. J. Dore ${ }^{1}$, Y. S. Tang ${ }^{1}$, N. van Dijk ${ }^{1}$, \\ R. M. Rees $^{2}$, C. McDonald ${ }^{2}$, S. Murray ${ }^{2}$, U. M. Skiba ${ }^{1}$, and M. A. Sutton ${ }^{1}$ \\ ${ }^{1}$ Centre for Ecology \& Hydrology $(\mathrm{CEH})$ Edinburgh, Bush Estate, Penicuik, EH26 0QB, UK \\ ${ }^{2}$ Scotland's Rural College (SRUC), King's Buildings, West Mains Road, Edinburgh, EH9 3JG, UK \\ ${ }^{3}$ Institute of Atmospheric and Environmental Science, School of GeoSciences, University of Edinburgh, King's Buildings, \\ West Mains Road, Edinburgh, EH9 3JN, UK \\ ${ }^{4}$ Higher Technical School of Agricultural Engineering, Technical University of Madrid (UPM), 28040 Madrid, Spain
}

Correspondence to: C. F. Braban (chri2@ceh.ac.uk)

Received: 21 June 2012 - Published in Biogeosciences Discuss.: 23 July 2012

Revised: 22 November 2012 - Accepted: 10 December 2012 - Published: 9 January 2013

\begin{abstract}
A comprehensive assessment of nitrogen ( $\mathrm{N}$ ) flows at the landscape scale is fundamental to understand spatial interactions in the $\mathrm{N}$ cascade and to inform the development of locally optimised $\mathrm{N}$ management strategies. To explore these interactions, complete $\mathrm{N}$ budgets were estimated for two contrasting hydrological catchments (dominated by agricultural grassland vs. semi-natural peat-dominated moorland), forming part of an intensively studied landscape in southern Scotland. Local scale atmospheric dispersion modelling and detailed farm and field inventories provided high resolution estimations of input fluxes. Direct agricultural inputs (i.e. grazing excreta, $\mathrm{N}_{2}$ fixation, organic and synthetic fertiliser) accounted for most of the catchment $\mathrm{N}$ inputs, representing $82 \%$ in the grassland and $62 \%$ in the moorland catchment, while atmospheric deposition made a significant contribution, particularly in the moorland catchment, contributing $38 \%$ of the $\mathrm{N}$ inputs. The estimated catchment $\mathrm{N}$ budgets highlighted areas of key uncertainty, particularly $\mathrm{N}_{2}$ exchange and stream $\mathrm{N}$ export. The resulting $\mathrm{N}$ balances suggest that the study catchments have a limited capacity to store $\mathrm{N}$ within soils, vegetation and groundwater. The "catchment $\mathrm{N}$ retention", i.e. the amount of $\mathrm{N}$ which is either stored within the catchment or lost through atmospheric emissions, was estimated to be $13 \%$ of the net anthropogenic input in the moorland and $61 \%$ in the grassland catchment. These values contrast with regional scale estimates: Catchment retentions of net anthropogenic input estimated within Europe at the regional scale range from $50 \%$ to $90 \%$, with an aver-
\end{abstract}

age of $82 \%$ (Billen et al., 2011). This study emphasises the need for detailed budget analyses to identify the $\mathrm{N}$ status of European landscapes.

\section{Introduction}

Human activities dominate the global nitrogen $(\mathrm{N})$ budget by adding reactive forms of nitrogen $\left(\mathrm{N}_{\mathrm{r}}\right)$ to the environment (Galloway et al., 2004). The main forms of anthropogenic $\mathrm{N}_{\mathrm{r}}$ are reduced (e.g. $\mathrm{NH}_{3}, \mathrm{NH}_{4}^{+}$), oxidised (e.g. $\mathrm{NO}_{2}, \mathrm{~N}_{2} \mathrm{O}$, $\mathrm{NO}_{3}^{-}$) and organic forms of $\mathrm{N}$ (e.g. urea). Between 1995 and 2005 alone, the anthropogenic production of $\mathrm{N}_{\mathrm{r}}$ increased by $20 \%$, which is largely due to agricultural activities (Galloway et al., 2008). The environmental consequences of $\mathrm{N}_{\mathrm{r}}$ input can be significant, such as a loss of biodiversity in terrestrial and aquatic ecosystems through eutrophication and acidification (Vitousek et al., 1997). Nitrogen budgets as indicators of environmental pressure have recently been developed and applied at various scales (de Vries et al., 2011a), ranging from the farm and field level (e.g. Ammann et al., 2009; Schröder et al., 2003) to the regional catchment (e.g. Billen et al., 2009; Howarth et al., 1996) and global scale (e.g. Bouwman et al., 2005; Seitzinger et al., 2005).

The assessment of budgets at the landscape scale is a critical part of quantifying the impact of disturbance on nutrient cycling (McDowell and Asbury, 1994). A landscape is defined as a spatially heterogeneous area that includes 
interacting ecosystems and extends from hectares to many square kilometres (Turner and Gardner, 1994). Nitrogen is transported between those ecosystems by atmospheric, hydrological and human transfers (Cellier et al., 2011). Fluxes of $\mathrm{N}_{\mathrm{r}}$ at the landscape scale are particularly relevant as both management decisions (e.g. through farm activities) and the environmental impacts occur at this scale, particularly in European rural landscapes (Cellier et al., 2011; Dalgaard et al., 2011; Kros et al., 2011; Sutton et al., 2007). This makes determining landscape $\mathrm{N}_{\mathrm{r}}$ fluxes important for environmental protection and policy makers, since a good understanding of the quantities and dynamics of $\mathrm{N}$ fluxes at the landscape scale is essential for designing effective regulations aimed at reducing environmental impacts. However, accurate estimation of $\mathrm{N}$ fluxes at high spatial resolution poses a significant challenge (de Vries et al., 2011a), e.g. the estimation of spatially variable $\mathrm{N}$ dry deposition represents one of the key uncertainties in quantifying $\mathrm{N}$ inputs to terrestrial ecosystems (Tang et al., 2009).

In this study, we estimated $\mathrm{N}$ budgets for two adjacent catchments at the landscape scale. The catchments contrast in their land use: one is dominated by semi-natural moorland, the other by grazed grassland. To the authors' knowledge, this is the first such study which includes high resolution atmospheric modelling combined with a detailed spatial landscape inventory of field-specific agricultural activities and intensive measurements of fluvial export. The study aims to assess how landscape $\mathrm{N}$ budget analysis provides an insight into the main $\mathrm{N}$ flux terms, key uncertainties associated with these terms, and the overall implications for the environmental status of the landscape.

\section{Methods}

\subsection{Study landscape}

As part of the NitroEurope Integrated Project (Sutton et al., 2007), a landscape study area of $6 \mathrm{~km} \times 6 \mathrm{~km}$ was established in southeast Scotland for detailed inventory of agricultural activities, $\mathrm{N}_{\mathrm{r}}$ concentration and flux measurements (see Vogt et al., 2012a, 2012b for further details). The area has a temperate oceanic climate with an annual mean temperature of $\sim 8^{\circ} \mathrm{C}$ and a typical rainfall of $\sim 1000 \mathrm{~mm}$. The study landscape was located to include the two contrasting catchments. The moorland peat-dominated catchment covered 621 ha, while the grassland dominated catchment covered 895 ha. Together these two catchments represent $42 \%$ of the study landscape (Fig. 1).

$1{ }^{\left({ }^{C}\right.}$ The James Hutton Institute 2011 (license MI/2008/296). Soil types are based on the Scottish Soil Survey, the equivalent FAO names are: brown forest soil=cambisol, mineral alluvial soil $=$ fluvisol, noncalcareous gley $=$ gleysol, peaty gley $=$ humic gleysol, peaty podzol = humic podzol, peat $=$ histosol, peaty alluvial soil = humic fluvisol.
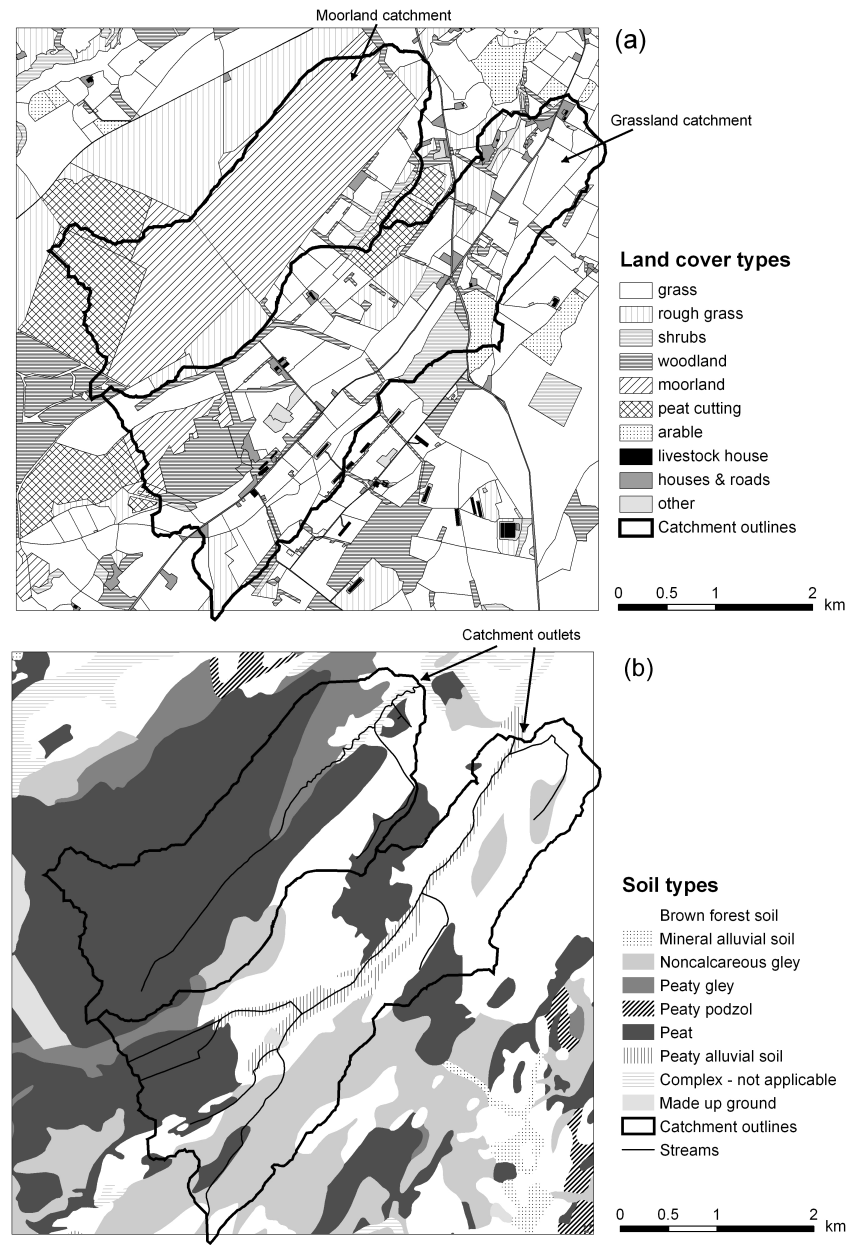

Fig. 1. Maps of land cover (a) and soil types ${ }^{1}$ (b) within the study landscape with outlines of the two studied catchments ${ }^{2}$.

A detailed local survey of all farms and fields in the study landscape was conducted throughout 2008. This provided land cover and farm activity data, which were collated into a relational database and spatially represented in a geographical information system (ArcGIS, ESRI). Land cover and soil types within the landscape, together with the boundaries of the two studied catchments, are shown in Fig. 1. Moorland and rough grass, including peat cutting and areas of both deciduous and coniferous afforestation, dominate the northwestern part of the landscape and the Black Burn catchment, whereas the southeast and the Lead Burn catchment is dominated by agricultural land (henceforth referred to as the Moorland and the Grassland catchments, respectively, Table 1). Agricultural activities in the landscape range from extensive beef cattle and sheep farming to intensive poultry

\footnotetext{
${ }^{2}$ Some features of these maps are based on data licensed from Intermap Technologies Inc. ${ }^{(C)} 2010$ Intermap Technologies Inc. All Rights Reserved.
} 
Table 1. Characteristics of the Moorland and the Grassland catchment.

\begin{tabular}{lrr}
\hline & $\begin{array}{r}\text { Moorland } \\
\text { catchment }\end{array}$ & $\begin{array}{r}\text { Grassland } \\
\text { catchment }\end{array}$ \\
\hline Area $\left(\mathrm{km}^{2}\right)$ & 6.2 & 8.9 \\
Average altitude & 270 & 280 \\
$\%$ main land cover types & & \\
$\quad$ Grassland & 11 & 59 \\
Rough grass & 10 & 10 \\
Moorland & 63 & 5 \\
Peat cutting & 12 & 2 \\
Woodland & 2 & 14 \\
$\%$ main soil types & & \\
Brown forest soils & 16 & 48 \\
Peat & 67 & 21 \\
Peaty gleys & 10 & 2 \\
Noncalcareous gleys & 5 & 22 \\
\hline
\end{tabular}

farming, with poultry houses in the study area containing nearly 1.5 mio. laying hens.

\subsection{Catchment $\mathrm{N}$ budgets}

Several recent studies have compared different budgetary approaches to quantify $\mathrm{N}$ balances in agricultural systems. Oenema et al. (2003) presented farm gate, soil surface and soil system budget methodologies, de Vries et al. (2011b) and Leip et al. (2011) presented regional farm, land and soil N budgets, all studies delineated inputs and outputs for each of these approaches. In our study, the Moorland and Grassland catchment annual $\mathrm{N}$ budgets were assessed for 2008 using a soil budgeting approach which most closely matches the soil $\mathrm{N}$ budget approach of de Vries et al. (2011b) (except the $\mathrm{N}$ pool changes), i.e. all $\mathrm{N}$ that enters and leaves the soil was accounted for. This type of approach was chosen as the inputs and outputs are directly associated with the catchment soils and linked to the downstream flux. The balance of the $\mathrm{N}$ input and output terms indicate the change in $\mathrm{N}$ storage within the catchment over time. There were significant $\mathrm{N}$ fluxes occurring in connection with the poultry housing, i.e. housing emissions and farming operations such as feed import, manure export or livestock export within one of the catchments, but for the purpose of a soil budget approach, housing emissions and farming operations not affecting the catchment land surface were considered decoupled from the soil. Thus they were excluded from this approach, except via the $\mathrm{N}$ deposition fluxes resulting from housing emissions.

The soil $\mathrm{N}$ budget was derived as follows:

$\Delta \mathrm{N} / \Delta t=\mathrm{N}_{\mathrm{NH}_{3} \text { dry dep }}+\mathrm{N}_{\mathrm{NH}_{\mathrm{x}} \text { wet dep }}+\mathrm{N}_{\mathrm{NO}_{\mathrm{y}} \text { dep }}+\mathrm{N}_{\text {syn fert }}+\mathrm{N}_{\text {org fert }}+\mathrm{N}_{\text {excreta }}$

$+\mathrm{N}_{\text {bio fix }}-\mathrm{N}_{\mathrm{NH}_{3}}-\mathrm{N}_{\mathrm{N}_{2} \mathrm{O}}-\mathrm{N}_{\mathrm{NO}}-\mathrm{N}_{\mathrm{N}_{2}}-\mathrm{N}_{\text {harvest }}-\mathrm{N}_{\text {grass }}-\mathrm{N}_{\text {stream }}$,

where $\Delta \mathrm{N} / \Delta t$ is the change in $\mathrm{N}$ balance $(\Delta \mathrm{N})$ over time

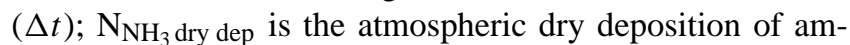
monia $\left(\mathrm{NH}_{3}\right) ; \mathrm{N}_{\mathrm{NH}_{\mathrm{x}} \text { wet dep }}$ is the atmospheric wet deposition
Table 2. Uncertainty classification.

\begin{tabular}{lll}
\hline Uncertainty class & Error & $\begin{array}{l}\text { Associated budget } \\
\text { terms }\end{array}$ \\
\hline Accurate & $\pm 10 \%$ & $\mathrm{~N}_{\text {syn fert }}$ \\
Low & $\pm 20 \%$ & $\mathrm{~N}_{\mathrm{NH}_{3} \text { dry dep }}$ \\
& & $\mathrm{N}_{\mathrm{NH}_{\mathrm{x}} \text { wet dep }}$ \\
& & $\mathrm{N}_{\mathrm{NO}_{\mathrm{y}} \text { dep }}$ \\
& & $\mathrm{N}_{\mathrm{NH}_{3}}$ \\
& & $\mathrm{~N}_{\text {harvest }}$ \\
& & $\mathrm{N}_{\text {stream }}$ \\
Moderate & & $\mathrm{N}_{\text {org fert }}$ \\
High & $\pm 30 \%$ & $\mathrm{~N}_{\text {excreta }}$ \\
& $\pm 50 \%$ & $\mathrm{~N}_{\text {grass }}$ \\
& & $\mathrm{N}_{\mathrm{N}_{2} \mathrm{O}}$ \\
& & $\mathrm{N}_{\mathrm{NO}}$ \\
Exceptionally high & Individually set & $\mathrm{N}_{\text {bio fix }}$ \\
& & $\mathrm{N}_{\mathrm{N}_{2}}$ \\
\hline
\end{tabular}

of reduced nitrogen $\left(\mathrm{NH}_{\mathrm{x}}\right) ; \mathrm{N}_{\mathrm{NO}_{\mathrm{y}} \text { dep }}$ is the atmospheric dry and wet deposition of oxidised nitrogen $\left(\mathrm{NO}_{\mathrm{y}}\right) ; \mathrm{N}_{\mathrm{syn} \text { fert }}$ is the $\mathrm{N}$ content in applied synthetic fertiliser; $\mathrm{N}_{\text {org fert }}$ is the $\mathrm{N}$ content in applied organic fertiliser; $\mathrm{N}_{\text {excreta }}$ is the amount of $\mathrm{N}$ excreted by grazing livestock; $\mathrm{N}_{\text {bio fix }}$ is the biological $\mathrm{N}_{2}$ fixation; $\mathrm{N}_{\mathrm{NH}_{3}}, \mathrm{~N}_{\mathrm{N}_{2} \mathrm{O}}, \mathrm{N}_{\mathrm{NO}}$ and $\mathrm{N}_{\mathrm{N}_{2}}$ are emissions of $\mathrm{NH}_{3}$, nitrous oxide $\left(\mathrm{N}_{2} \mathrm{O}\right)$, nitric oxide $(\mathrm{NO})$ and $\mathrm{N}_{2}$ to the atmosphere; $\mathrm{N}_{\text {harvest }}$ is the $\mathrm{N}$ offtake through harvested vegetation for silage and hay production; $\mathrm{N}_{\text {grass }}$ is the $\mathrm{N}$ offtake through harvested grass by grazing livestock; $\mathrm{N}_{\text {stream }}$ is the downstream export flux of total dissolved nitrogen (TDN).

Uncertainty classes were assigned to individual budget terms depending on the accuracy of the data source (Table 2) using a similar classification scheme as in Kros et al. (2012). The overall uncertainty of the $\mathrm{N}$ balance $\left(E_{\Delta \mathrm{N} / \Delta t}\right)$ was calculated as the square root of the sum of the error $(E)$ squares, hereby accounting for the depending variables $\mathrm{N}_{\text {grass }}$ and $\mathrm{N}_{\text {excreta: }}$ :

$$
\begin{aligned}
& E_{\Delta \mathrm{N} / \Delta t}=\operatorname{sqrt}\left[\left(E_{\mathrm{NH}_{3} \text { dry dep }}\right)^{2}+\left(E_{\mathrm{NH}_{\mathrm{x}} \text { wet dep }}\right)^{2}+\left(E_{\mathrm{NO}_{\mathrm{y}} \text { dep }}\right)^{2}\right. \\
& +\left(E_{\text {syn fert }}\right)^{2}+\left(E_{\text {org fert }}\right)^{2}+\left(E_{\text {grass }}-E_{\text {excreta }}\right)^{2}+\left(E_{\text {bio fix }}\right)^{2} \\
& \left.+\left(E_{\mathrm{NH}_{3}}\right)^{2}+\left(E_{\mathrm{N}_{2} \mathrm{O}}\right)^{2}+\left(E_{\mathrm{NO}}\right)^{2}+\left(E_{\mathrm{N}_{2}}\right)^{2}+\left(E_{\text {harvest }}\right)^{2}+\left(E_{\text {stream }}\right)^{2}\right] .
\end{aligned}
$$

In the following sections the method of quantifying individual budget terms and their uncertainties is described.

\subsection{Catchment $\mathrm{N}$ inputs}

\subsubsection{Atmospheric deposition}

The spatial and temporal variability of atmospheric $\mathrm{NH}_{3}$ across the landscape, in which the two catchments are contained, was described in detail by Vogt et al. (2012b). Monthly mean $\mathrm{NH}_{3}$ concentrations at 31 sites were measured through 2008 with ALPHA passive diffusion samplers (Tang et al., 2001). Sites were distributed across the study 
landscape with an emphasis on capturing high and low emission areas as well as the variability around sources. Ammonia emissions were calculated for each individual field, manure store and livestock house, based on the field and farm activities recorded on a monthly basis, combined with emission rates for each activity (manure housing, storage and spreading, grazing and fertiliser application, Vogt et al., 2012b). The emission estimates were used in the Local Area Dispersion and Deposition model (LADD) (Hill, 1998; Loubet et al., 2009) at a resolution of $25 \mathrm{~m} \times 25 \mathrm{~m}$ to model spatial concentrations and dry deposition of $\mathrm{NH}_{3}$ within the study landscape. Measured annual mean concentrations of the 31 sampling sites were used for verification of the LADD model. As $\mathrm{NH}_{3}$ has a high dry deposition rate (Cellier et al., 2011) and is thus expected to be driven by local sources, $\mathrm{NH}_{3}$ dry deposition inputs to the studied catchments $\left(\mathrm{N}_{\mathrm{NH}_{3}}\right.$ dry dep $)$ were calculated from fluxes modelled by LADD within the study landscape only (accounting for atmospheric $\mathrm{NH}_{3}$ import to the landscape using national modelling). The $\mathrm{N}$ budget term is considered to carry a low uncertainty of $\pm 20 \%$ in this instance, due to the detailed local study involving an intensive measurement programme and local atmospheric dispersion modelling.

Catchment atmospheric inputs due to $\mathrm{NH}_{\mathrm{x}}$ wet deposition $\left(\mathrm{N}_{\mathrm{NH}_{\mathrm{x}} \text { wet dep }}\right)$ and dry and wet deposition of $\mathrm{NO}_{\mathrm{y}}\left(\mathrm{N}_{\mathrm{NO}_{\mathrm{y}} \mathrm{dep}}\right)$, which are expected to be largely driven by non-local sources (e.g. Hertel et al., 2011; Sutton et al., 1998), were simulated by the UK national model FRAME (Fine Resolution Atmospheric Multi-pollutant Exchange) (Dore et al., 2012; Dore et al., 2007; Hallsworth et al., 2010) at a resolution of $1 \mathrm{~km} \times 1 \mathrm{~km}$. The contribution of particulate ammonium $\left(\mathrm{NH}_{4}^{+}\right)$to $\mathrm{NH}_{\mathrm{x}}$ dry deposition is considered minor compared to $\mathrm{NH}_{3}$ (e.g. Asman et al., 1998; Duyzer, 1994). FRAME simulations were combined with land cover data of $25 \mathrm{~m} \times 25 \mathrm{~m}$ resolution in order to apply land cover specific deposition rates to different land cover types, as described in detail by Vogt et al. (2012b). For the atmospheric inputs of $\mathrm{NH}_{\mathrm{x}}$ wet deposition and the dry and wet deposition of $\mathrm{NO}_{\mathrm{y}}$, national modelling at a relatively fine-scale resolution, applied to local land cover data, is considered to deliver adequate deposition estimates for this purpose with a low uncertainty in the range of $\pm 20 \%$.

\subsubsection{Agricultural land surface input}

Agricultural inputs to the land surface through applications of synthetic fertiliser $\left(\mathrm{N}_{\text {syn fert }}\right)$, organic fertiliser $\left(\mathrm{N}_{\text {org fert }}\right)$ and excreta of grazing livestock $\left(\mathrm{N}_{\text {excreta }}\right)$ were derived from farm activity data (Vogt et al., 2012a). A typical $\mathrm{N}$ content was used for the different manure types (Defra, 2010). The $\mathrm{N}$ input from grazing livestock was estimated using grazing records and daily $\mathrm{N}$ excretion data as used in the $\mathrm{UK} \mathrm{NH}_{3}$ inventory (Misselbrook et al., 2009). Nitrogen inputs from applications of synthetic fertiliser are considered accurate, as this value is known by individual farmers (estimated uncer- tainty $\pm 10 \%$ ). A moderate uncertainty of $\pm 30 \%$ is associated with the $\mathrm{N}$ input through applications of organic fertiliser, as a typical $\mathrm{N}$ content was applied to different manure types as specified by the farmer. The uncertainty associated with the $\mathrm{N}$ input through grazing livestock excreta is estimated to be high $( \pm 50 \%)$ as the $\mathrm{N}$ content of the grazed grass is not known.

\subsubsection{Biological $\mathrm{N}_{2}$ fixation}

Experimentally derived data on biological $\mathrm{N}_{2}$ fixation are rare in the literature. DeLuca et al. (2008) measured fixation rates to mainly range between 1 and $2 \mathrm{~kg} \mathrm{Nha}^{-1} \mathrm{yr}^{-1}$ in a Swedish boreal forest; Limmer and Drake (1996) cite a mean fixation rate of $1 \mathrm{~kg} \mathrm{Nha}^{-1} \mathrm{yr}^{-1}$ from studies conducted in European and North American forests and Waughman and Bellamy (1980) measured a fixation rate of $0.7 \mathrm{~kg} \mathrm{Nha}^{-1} \mathrm{yr}^{-1}$ in German bogs. The catchment $\mathrm{N}$ input through biological $\mathrm{N}_{2}$ fixation $\left(\mathrm{N}_{\text {bio fix }}\right.$ ) was thus estimated to be $1 \mathrm{~kg} \mathrm{Nha}^{-1} \mathrm{yr}^{-1}$ for the Moorland catchment. As there was little or no clover in most of the grassland, $\mathrm{N}_{\text {bio fix }}$ for the Grassland catchment was estimated to be $5 \mathrm{~kg} \mathrm{Nha}^{-1} \mathrm{yr}^{-1}$. This is in agreement with grassland fixation rates used by various $\mathrm{N}$ budget models compared by de Vries et al. (2011b). The $\mathrm{N}$ input through biological $\mathrm{N}_{2}$ fixation carries an exceptionally high uncertainty $(-70 /+300 \%)$ as this term is estimated from only a few experimentally derived literature values.

\subsection{Catchment N outputs}

\subsubsection{Gaseous emissions from land surfaces}

Ammonia emissions were calculated by applying UK average emission factors (EFs) of the UK emission inventory to the land surface inputs from synthetic and organic fertiliser and grazing excreta (Misselbrook et al., 2009). The housing emissions and manure storage emissions were excluded from the calculation of catchment budgets as discussed in Sect. 2.2. As calculations of $\mathrm{NH}_{3}$ emissions are based on the local farm inventory and national emission factors, the uncertainty is estimated to be low $( \pm 20 \%)$.

Direct $\mathrm{N}_{2} \mathrm{O}$ emissions are associated with soil $\mathrm{N}$ input $\left(\mathrm{N}_{\mathrm{NH}_{3} \text { dry dep }}+\mathrm{N}_{\mathrm{NH}_{\mathrm{x}} \text { wet dep }}+\mathrm{N}_{\mathrm{NO}_{\mathrm{y}} \text { dep }}+\mathrm{N}_{\text {syn fert }}+\mathrm{N}_{\text {org fert }}\right.$ $+\mathrm{N}_{\text {excreta }}$ ) and were calculated using the method of Lesschen et al. (2011), which uses specific EFs depending on the source of $\mathrm{N}$ input, soil type and annual precipitation. The clay soil EF parameterisation in Lesschen et al. (2011) was selected linked to the modification of the catchment surface soils by agricultural activity. The local 2008 annual precipitation of $1208 \mathrm{~mm}$ was used to derive a precipitation adjustment factor $\left(f_{\mathrm{p}}\right)$ in the method of Lesschen et al. (2011) of 2.16. Peat cutting areas and other peat bog areas without agricultural activities are assumed to have insignificant $\mathrm{N}_{2} \mathrm{O}$ emissions due to soil $\mathrm{C} / \mathrm{N}$ ratios exceeding 
25 (Klemedtsson et al., 2005). Also, measurements within the Moorland catchment showed negligible $\mathrm{N}_{2} \mathrm{O}$ emissions (Drewer et al., 2010). Indirect $\mathrm{N}_{2} \mathrm{O}$ emissions, i.e. degassing of $\mathrm{N}_{2} \mathrm{O}$ from waters resulting from soil leaching, were estimated using the 2009 IPCC Guidelines (De Klein et al., 2009).

Emissions of NO were derived by applying a Tier $1 \mathrm{EF}$ of $2.6 \%$ to synthetic fertiliser $\mathrm{N}$ applied as recommended in the EEA/EMEP guidelines (McGlade and Vidic, 2009). As there is no specific EF recommended for applications of organic fertiliser and grazing livestock excreta a literature value of $0.5 \%$ was applied (Bouwman et al., 2002).

The uncertainty of $\mathrm{N}_{2} \mathrm{O}$ and $\mathrm{NO}$ emissions is estimated to be high $( \pm 50 \%)$, as they are based on data from the farm inventory and also literature emission factors. Emissions are known to vary substantially depending on soil conditions.

Emission factors of $\mathrm{N}_{2}$ are highly uncertain. Recently, Ammann et al. (2009) applied a literature-derived EF of $12.5 \%$ to $\mathrm{N}$ inputs from fertilisation and biological $\mathrm{N}_{2}$ fixation for a Swiss grassland with an error of $\pm 100 \%$. For a grazed grassland in southeast Scotland $(<10 \mathrm{~km}$ from this study landscape), $\mathrm{N}_{2}$ emissions were modelled and an EF of $10 \%$ of applied $\mathrm{N}$ through grazing excreta and synthetic and organic fertilisation calculated (U. M. Skiba, personal communication, 2011). This $\mathrm{N}_{2} \mathrm{EF}$ was applied to all fields with agricultural activities in our study catchments. It is noted that there is an exceptionally high uncertainty $(-50 /+200 \%)$ associated with this budget term (Sects. 3.3 and 3.4).

\subsubsection{Harvested vegetation}

Nitrogen output also occurs via removal of vegetation by harvesting ( $\mathrm{N}_{\text {harvest }}$ ) and by grazing livestock $\left(\mathrm{N}_{\text {grass }}\right)$. The amount of harvested crop and grass removed by farmers for silage and hay production was derived from the farm survey activity data with a specific $\mathrm{N}$ content applied to each main crop type (Møller et al., 2005). The uncertainty of $\mathrm{N}_{\text {harvest }}$ is thus estimated to be low $( \pm 20 \%)$. The amount of $\mathrm{N}$ removed through grass consumption by grazing livestock $\left(\mathrm{N}_{\text {grass }}\right)$ was estimated as follows:

$\mathrm{N}_{\text {grass }}=\mathrm{N}_{\text {excreta }}+\mathrm{N}_{\text {animal }}-\mathrm{N}_{\text {feed }}$,

where $\mathrm{N}_{\text {excreta }}$ is the amount of $\mathrm{N}$ excreted by grazing livestock (Sect. 2.3.2), $\mathrm{N}_{\text {animal }}$ is the $\mathrm{N}$ content in the exported wool and meat, calculated using $\mathrm{N}$ content values in Roche (1995) and Flindt (2003) and $\mathrm{N}_{\text {feed }}$ is the $\mathrm{N}$ content of the supplementary animal feed, derived by farm activity data and a specific $\mathrm{N}$ content of different feed types (Møller et al., 2005). Both $\mathrm{N}_{\text {animal }}$ and $\mathrm{N}_{\text {feed }}$ are estimated to have a low uncertainty of $\pm 20 \%$, however considering the high uncertainty associated with $\mathrm{N}_{\text {excreta }}$, the uncertainty of $\mathrm{N}_{\text {grass }}$ is estimated to be high $( \pm 50 \%)$.

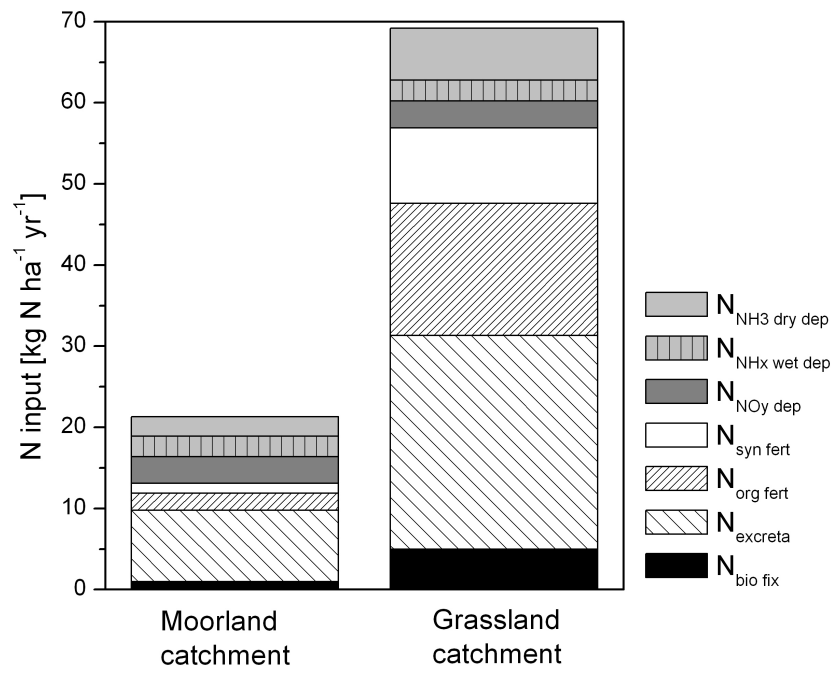

Fig. 2. $\mathrm{N}$ inputs $\left(\mathrm{kg} \mathrm{Nha}^{-1} \mathrm{yr}^{-1}\right)$ to the Moorland (left) and the Grassland catchment (right).

\subsubsection{Fluvial export}

Annual downstream fluxes $\left(\mathrm{N}_{\text {stream }}\right)$ of total dissolved nitrogen (TDN), which is the sum of ammonium $\left(\mathrm{NH}_{4}^{+}-\mathrm{N}\right)$, nitrate $\left(\mathrm{NO}_{3}^{-}-\mathrm{N}\right)$ and dissolved organic nitrogen $(\mathrm{DON})$, were established by Vogt et al. (2012a) by sampling at gauged outlets of the two catchments at both fortnightly and hourly intervals during selected high flow events through 2008. As $\mathrm{N}_{\text {stream }}$ is based on local measurements conducted throughout the study year, it is considered to carry a low uncertainty, conservatively estimated at $\pm 20 \%$. Additional information on sources of streamwater $\mathrm{N}$ concentrations within the catchments was derived by spatial sampling at stable low flow conditions, conducted in July, September and December 2008.

\section{Results and discussion}

The outcomes are explored here using spatially differentiated results of the agricultural land surface $\mathrm{N}$ input, the associated land surface $\mathrm{N}$ emissions and atmospheric $\mathrm{N}$ deposition and fluvial $\mathrm{N}$ export. In addition, the catchment $\mathrm{N}$ inputs and output terms are summarised and the overall catchment $\mathrm{N}$ budgets are given with a discussion of uncertainty.

\subsection{N inputs to land in the study catchments}

The various components which contribute $\mathrm{N}$ inputs to the two study catchments are summarised in Fig. 2 (input estimates expressed per hectare). Overall, the inputs to the Grassland catchment $\left(69.2 \mathrm{~kg} \mathrm{Nha}^{-1} \mathrm{yr}^{-1}\right)$ were more than three times higher than those to the Moorland catchment $\left(21.3 \mathrm{~kg} \mathrm{Nha}^{-1} \mathrm{yr}^{-1}\right)$. Inputs were largely driven by direct agricultural land surface inputs. In the Grassland catchment, $82 \%$ of all $\mathrm{N}$ inputs originated from direct agricultural land 


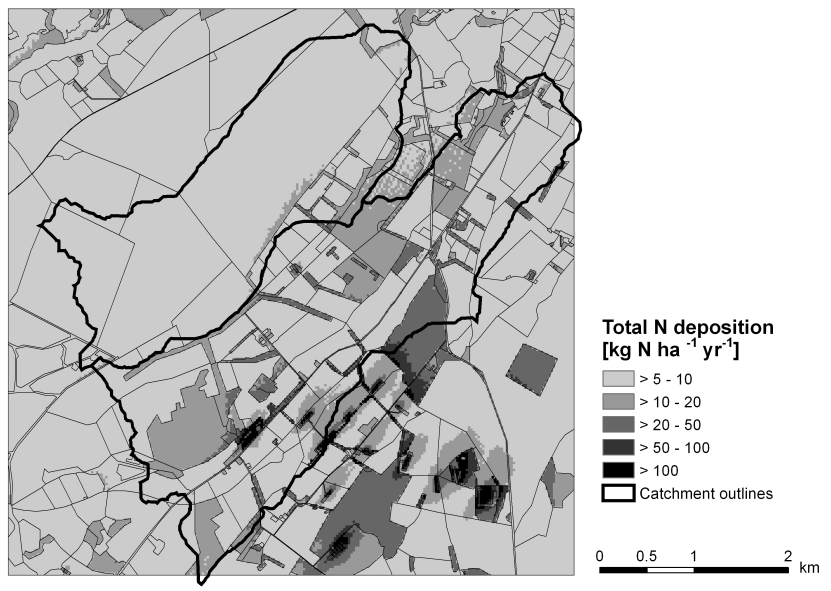

Fig. 3. Map of estimated total $\mathrm{N}$ deposition within the study landscape. Source: Vogt et al. (2012b).

surface inputs and $18 \%$ from atmospheric $\mathrm{N}$ deposition. Atmospheric deposition accounted for a larger contribution in the Moorland catchment with $38 \%$ of all $\mathrm{N}$ inputs. However, the majority (62\%) originated from direct agricultural land surface inputs. Grazing livestock excreta represented the largest single input source, contributing $41 \%$ to the inputs in the Moorland and $38 \%$ in the Grassland catchment. The fraction of the grazing excreta subject to gaseous emissions to the atmosphere (Sect. 3.2.1) was estimated to be around $21 \%$, thus the majority of the catchment input through grazing excreta stayed either within the system, i.e. in soil or vegetation, or was leached into surface or groundwaters.

\subsubsection{Atmospheric $\mathbf{N}$ deposition}

The total atmospheric $\mathrm{N}$ deposition to the two studied catchments was estimated to be $8.2 \mathrm{~kg} \mathrm{Nha}^{-1} \mathrm{yr}^{-1}$ in the Moorland and $12.3 \mathrm{~kg} \mathrm{Nha}^{-1} \mathrm{yr}^{-1}$ in the Grassland catchment (Fig. 3). The dry deposition of $\mathrm{NH}_{3}$ to the study catchments $\left(\mathrm{N}_{\mathrm{NH}_{3} \text { dry dep }}\right)$ was estimated by modelling emissions of all agricultural $\mathrm{NH}_{3}$ sources within the study landscape, including housing and manure storage emissions (Sect. 2.3.1). Dry deposition of $\mathrm{NH}_{3}$ showed a high spatial variability at $25 \mathrm{~m} \times 25 \mathrm{~m}$ grid resolution within the catchments, ranging from 0.1 to $23 \mathrm{~kg} \mathrm{Nha}^{-1} \mathrm{yr}^{-1}$ in the Moorland (mean: $2.4 \mathrm{~kg} \mathrm{Nha}^{-1} \mathrm{yr}^{-1}$ ) and from 0.2 to $>100 \mathrm{~kg} \mathrm{Nha}^{-1} \mathrm{yr}^{-1}$ in the Grassland catchment (mean: $6.4 \mathrm{~kg} \mathrm{Nha}^{-1} \mathrm{yr}^{-1}$ ). The larger input to the Grassland catchment was due to the catchment containing six intensive poultry farming houses with a total $\mathrm{NH}_{3}$ emission of $28 \mathrm{t} \mathrm{N} \mathrm{yr}^{-1}$.

Catchment inputs from $\mathrm{NH}_{\mathrm{x}}$ wet deposition were similar for both catchments $\left(2.5\right.$ and $2.6 \mathrm{~kg} \mathrm{Nha}^{-1} \mathrm{yr}^{-1}$, respectively), as were inputs from $\mathrm{NO}_{\mathrm{y}}$ deposition (both $3.3 \mathrm{~kg} \mathrm{Nha}^{-1} \mathrm{yr}^{-1}$ ). Atmospheric deposition to the Moorland catchment was estimated to be driven by non-local sources with $\mathrm{N}_{\mathrm{NH}_{\mathrm{x}} \text { wet dep }}$ and $\mathrm{N}_{\mathrm{NO}_{\mathrm{y}} \text { dep }}$ contributing $71 \%$ to the total $\mathrm{N}$ deposition, while $52 \%$ of deposition to the Grassland catchment was estimated to originate from local sources $\left(\mathrm{N}_{\mathrm{NH}_{3} \text { dry dep }}\right)$ and $48 \%$ from non-local sources $\left(\mathrm{N}_{\mathrm{NH}_{\mathrm{x}} \text { wet dep }}+\mathrm{N}_{\mathrm{NO}_{\mathrm{y}} \text { dep }}\right)$.

\subsubsection{Agricultural land surface $\mathrm{N}$ input}

Agricultural $\mathrm{N}$ inputs to the land surface $\left(\mathrm{N}_{\text {syn fert }}, \mathrm{N}_{\text {org fert }}\right.$, $\mathrm{N}_{\text {excreta }}, \mathrm{N}_{\text {bio fix }}$ ) were dominated by grazing excreta in both catchments: in the Moorland catchment, grazing excreta contributed $67 \%$, organic fertiliser $16 \%$, synthetic fertiliser $9 \%$ and $\mathrm{N}_{2}$ fixation $8 \%$ to the land surface input; in the Grassland catchment, grazing excreta contributed $46 \%$, organic fertiliser $29 \%$, synthetic fertiliser $16 \%$ and $\mathrm{N}_{2}$ fixation $9 \%$. Most of the $\mathrm{N}$ in grazing excreta originated from sheep with contributions of $89 \%$ in the Moorland and $69 \%$ in the Grassland catchment. Fields within the Grassland catchment received more than four times the land surface $\mathrm{N}$ input ( $56.9 \mathrm{~kg} \mathrm{~N} \mathrm{ha}^{-1} \mathrm{yr}^{-1}$ ) than fields in the Moorland catchment $\left(13.1 \mathrm{~kg} \mathrm{Nha}^{-1} \mathrm{yr}^{-1}\right)$. The range of land surface inputs between fields was large, varying from 1 to $262 \mathrm{~kg} \mathrm{~N} \mathrm{ha}^{-1} \mathrm{yr}^{-1}$ in the Moorland and up to $351 \mathrm{~kg} \mathrm{Nha}^{-1} \mathrm{yr}^{-1}$ in the Grassland catchment.

No fields of the study landscape are located within a Nitrate Vulnerable Zone (NVZ), thus agricultural practice is not restricted by the Nitrate Directive (Defra, 2012), under which a maximum of $170 \mathrm{~kg} \mathrm{~N} \mathrm{ha}^{-1} \mathrm{yr}^{-1}$ of organic manures is set. In the present study, only $1 \%$ of the Moorland and $4.5 \%$ of Grassland catchment received manure, through organic fertiliser applications or grazing excreta, exceeding $170 \mathrm{~kg} \mathrm{~N} \mathrm{ha}^{-1} \mathrm{yr}^{-1}$, although it is noted that there are significant uncertainties associated with the calculation of these $\mathrm{N}$ inputs.

\section{2 $\mathrm{N}$ outputs from land in the study catchments}

Catchment outputs are shown as per hectare values in Fig. 4. The gaseous land surface emissions of $\mathrm{N}_{\mathrm{r}}$ $\left(\mathrm{N}_{\mathrm{NH}_{3}}+\mathrm{N}_{\mathrm{N}_{2} \mathrm{O}}+\mathrm{N}_{\mathrm{NO}}\right)$ led to losses of $1.7 \mathrm{~kg} \mathrm{Nha}^{-1} \mathrm{yr}^{-1}$ from the Moorland and $7.3 \mathrm{~kg} \mathrm{Nha}^{-1} \mathrm{yr}^{-1}$ from the Grassland catchment. Whereas emissions of $\mathrm{N}_{2} \mathrm{O}$ are similar to those of $\mathrm{NH}_{3}$ in the Moorland catchment, emissions from the Grassland catchment were dominated by $\mathrm{NH}_{3}$ emissions $(62 \%)$. Emissions of $\mathrm{NO}$ were relatively insignificant in both catchments: $0.1 \mathrm{~kg} \mathrm{Nha}^{-1} \mathrm{yr}^{-1}$ in the Moorland and $0.3 \mathrm{~kg} \mathrm{~N} \mathrm{ha}^{-1} \mathrm{yr}^{-1}$ in the Grassland. The estimated $\mathrm{N}_{2}$ emissions were large compared with the $\mathrm{N}_{\mathrm{r}}$ fluxes of the catchments, contributing $42 \%$ to the overall $\mathrm{N}$ emission flux from both catchments. However, the uncertainty within the $\mathrm{N}_{2}$ emission estimations is large (see Table 3).

Grazed grass $\left(\mathrm{N}_{\text {grass }}\right)$ constituted a large output term in both catchments, contributing $45 \%$ to the overall catchment output in the Moorland and $46 \%$ in the Grassland catchment. However, these losses were mostly recycled back to the soil by grazing livestock excreta $\left(\mathrm{N}_{\text {excreta }}\right)$ with $\mathrm{N}_{\text {excreta }}$ 


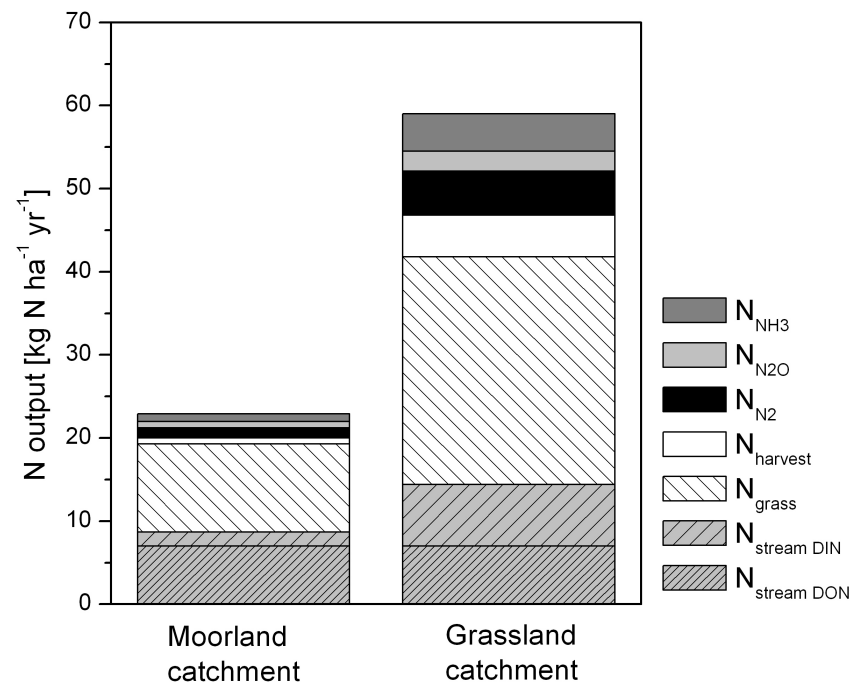

Fig. 4. $\mathrm{N}$ outputs $\left(\mathrm{kg} \mathrm{Nha}^{-1} \mathrm{yr}^{-1}\right)$ to the Moorland (left) and the Grassland catchment (right). Stream TDN export fluxes $\left(\mathrm{N}_{\text {stream }}\right)$ are split into the dissolved inorganic flux $\left(\mathrm{N}_{\text {stream DIN }}=\right.$ fluxes of $\mathrm{NH}_{4}^{+}$and $\left.\mathrm{NO}_{3}^{-}\right)$and the dissolved organic flux $\left(\mathrm{N}_{\text {stream DON }}\right)$.

representing $83 \%$ of $\mathrm{N}_{\text {grass }}$ in the Moorland and $96 \%$ of $\mathrm{N}_{\text {grass }}$ in the Grassland catchment. Thus, the main importance of this "grazing livestock $\mathrm{N}$ cycle" are increased rates of soil $\mathrm{N}$ cycling associated with the grazing excreta, which lead to gaseous and streamwater losses. When considering the grazed grass as a recycling budget term, the largest output fluxes of both catchments were the stream exports.

\subsubsection{Atmospheric N emissions}

Gaseous $\mathrm{NH}_{3}$ emissions from the catchment land surface (excluding housing and manure store emissions) are shown in Fig. 5a. In the Moorland catchment, fieldbased emissions ranged from 0 to $48 \mathrm{~kg} \mathrm{~N} \mathrm{ha}^{-1} \mathrm{yr}^{-1}$ (mean: $0.9 \mathrm{~kg} \mathrm{~N} \mathrm{ha}^{-1} \mathrm{yr}^{-1}$ ) with $58 \%$ originating from applications of organic fertiliser, $40 \%$ from grazing excreta and $2 \%$ from synthetic fertiliser. In the Grassland catchment, $\mathrm{NH}_{3}$ emissions ranged from 0 to $53 \mathrm{~kg} \mathrm{Nha}^{-1} \mathrm{yr}^{-1}$ between individual fields (mean: $4.5 \mathrm{~kg} \mathrm{~N} \mathrm{ha}^{-1} \mathrm{yr}^{-1}$ ) with $66 \%$ arising from organic fertiliser, $30 \%$ from grazing excreta and $4 \%$ from synthetic fertiliser. Despite most of the agricultural land surface input originating from grazing excreta (Sect. 3.1.2), the dominant source of $\mathrm{NH}_{3}$ emissions were applications of organic fertiliser in both catchments, due to high $\mathrm{NH}_{3}$ volatilisation losses. In contrast, almost all $\mathrm{N}$ in grazing excreta $(\sim 95 \%)$ can be expected to enter the catchment soils and thus contribute to soil emissions of $\mathrm{N}_{2} \mathrm{O}$ and $\mathrm{N}_{2}$ or can be leached. Overall, $7 \%$ of the agricultural land surface input of $\mathrm{N}$ to the Moorland catchment was estimated to be emitted as $\mathrm{NH}_{3}$ compared with $9 \%$ from the Grassland catchment.

Direct $\mathrm{N}_{2} \mathrm{O}$ emissions from the Moorland catchment averaged to $0.8 \mathrm{~kg} \mathrm{~N} \mathrm{ha}^{-1} \mathrm{yr}^{-1}$ with field emissions ranging from

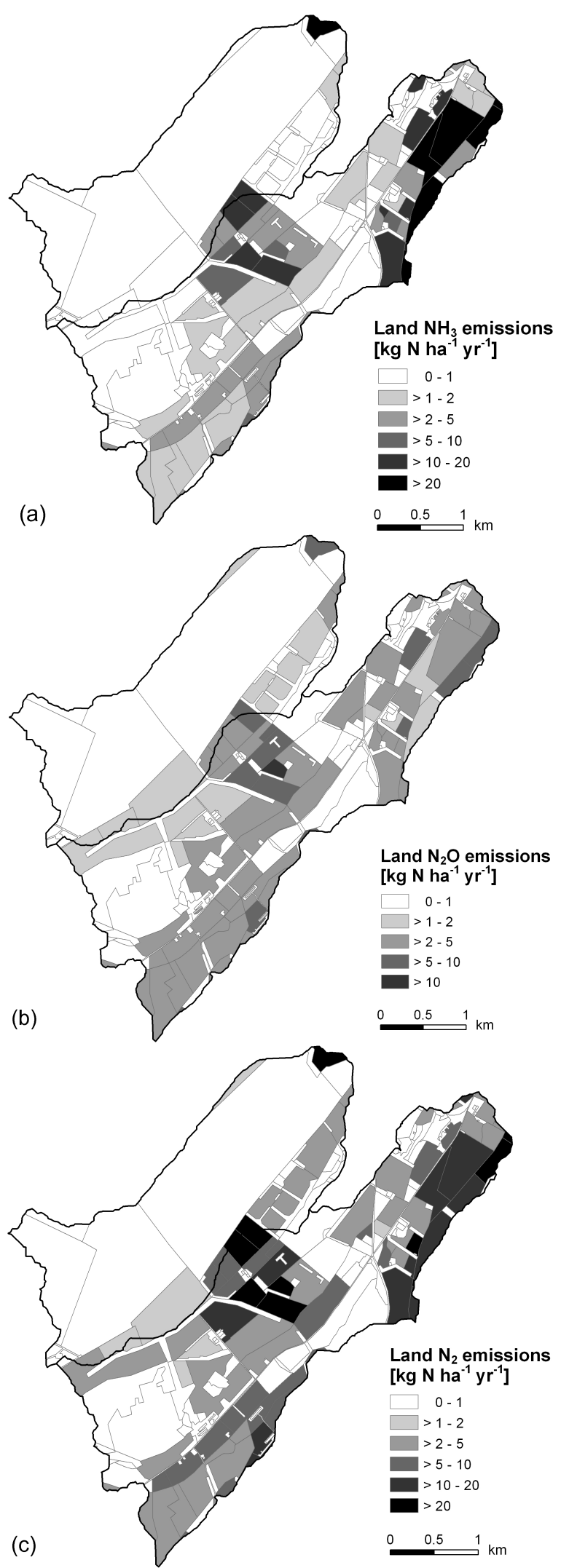

Fig. 5. Field-specific land surface emission maps of (a) $\mathrm{NH}_{3}$ emissions, (b) direct $\mathrm{N}_{2} \mathrm{O}$ emissions, and (c) direct $\mathrm{N}_{2}$ emissions. 
0 to $7.0 \mathrm{~kg} \mathrm{Nha}^{-1} \mathrm{yr}^{-1}$ (Fig. 5b). The Grassland catchment emitted $2.4 \mathrm{~kg} \mathrm{Nha}^{-1} \mathrm{yr}^{-1}$ as $\mathrm{N}_{2} \mathrm{O}$ with emissions ranging from 0.4 to $12.5 \mathrm{~kg} \mathrm{Nha}^{-1} \mathrm{yr}^{-1}$ between fields. Most of the direct $\mathrm{N}_{2} \mathrm{O}$ emissions were from grazing excreta $(79 \%$ in the Moorland and $75 \%$ in the Grassland catchment). Around $7 \%$ of the grazing excreta were estimated to be lost as $\mathrm{N}_{2} \mathrm{O}$ in both catchments. Figure $5 \mathrm{c}$ shows field emissions of $\mathrm{N}_{2}$ within the catchments. In the Moorland catchment, $\mathrm{N}_{2}$ emissions $\left(1.2 \mathrm{~kg} \mathrm{Nha}^{-1} \mathrm{yr}^{-1}\right.$ ) are estimated to be similar to $\mathrm{N}_{2} \mathrm{O}$ emissions, whereas in the Grassland catchment, $\mathrm{N}_{2}$ emissions ( $\left.5.3 \mathrm{~kg} \mathrm{Nha}^{-1} \mathrm{yr}^{-1}\right)$ are about 2.5 times higher than $\mathrm{N}_{2} \mathrm{O}$ emissions. Emissions per field ranged from 0 to $26.3 \mathrm{~kg} \mathrm{Nha}^{-1} \mathrm{yr}^{-1}$ in the Moorland and from 0 to $36.2 \mathrm{~kg} \mathrm{Nha}^{-1} \mathrm{yr}^{-1}$ in the Grassland catchment. However, the uncertainties within those field-based emission estimates were relatively large (Table 3 ) as there is substantial within field variation of $\mathrm{N}_{2} \mathrm{O}$ and $\mathrm{N}_{2}$ emissions due to the heterogeneity of soil processes (e.g. Hofstra and Bouwman, 2005).

Soil NO emissions were estimated to be insignificant for both catchments with emissions of $0.1 \mathrm{~kg} \mathrm{Nha}^{-1} \mathrm{yr}^{-1}$ in the Moorland and of $0.3 \mathrm{~kg} \mathrm{Nha}^{-1} \mathrm{yr}^{-1}$ in the Grassland catchment. The field with the highest NO emission was common to both catchments, thus the field-specific emission range of 0 to $1.8 \mathrm{~kg} \mathrm{Nha}^{-1} \mathrm{yr}^{-1}$ was the same for both catchments.

\subsubsection{Fluvial $N$ export}

Both catchments were characterised by highly variable stream flow with high discharge events making an important contribution to annual downstream fluxes (Vogt et al., 2012a). For example, in 2008, the highest $10 \%$ of the discharge data contributed $53 \%$ to the total discharge in the Moorland and $40 \%$ in the Grassland catchment. The annual downstream flux $\left(\mathrm{N}_{\text {stream }}\right)$ of total dissolved nitrogen (TDN) was $8.7 \mathrm{~kg} \mathrm{Nha}^{-1} \mathrm{yr}^{-1}$ in the Moorland and $14.4 \mathrm{~kg} \mathrm{Nha}^{-1} \mathrm{yr}^{-1}$ in the Grassland catchment. The difference in the TDN flux was mainly due to the significantly larger nitrate $\left(\mathrm{NO}_{3}^{-}\right)$flux in the Grassland catchment. Dissolved organic nitrogen (DON) contributed $81 \%$ to the TDN flux in the Moorland and $49 \%$ in the Grassland catchment. However, the absolute annual DON flux of $7.0 \mathrm{~kg} \mathrm{~N} \mathrm{ha}^{-1} \mathrm{yr}^{-1}$ was very similar in both catchments.

Maps of annual mean concentrations of $\mathrm{NO}_{3}^{-}, \mathrm{NH}_{4}^{+}$and DON measured during the three spatial sampling campaigns are shown in Fig. 6, together with the underlying land cover. The streamwater $\mathrm{NO}_{3}^{-}$concentrations of both catchments have been shown to be significantly positively related to $\mathrm{N}$ input through agricultural land surface and atmospheric deposition (Vogt et al., 2012a). Ammonium concentrations were significantly negatively related to $\mathrm{N}$ input and could be related to the coverage of wet peaty soils (Vogt et al., 2012a). However, local point source contributions, such as suspected sewage discharge observed while collecting samples, may also contribute to the large spatial variability of $\mathrm{NH}_{4}^{+}$concentrations within the Grassland catchment. The sources of
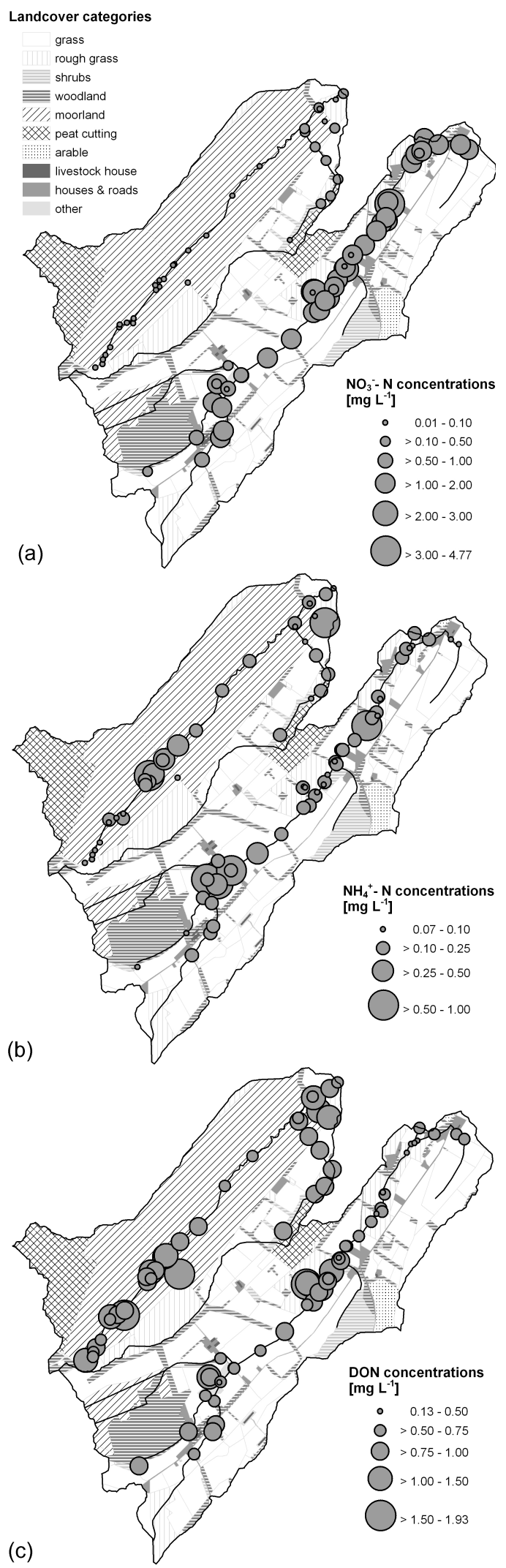

Fig. 6. Maps of annual mean concentrations derived from spatial samplings in July, September and December 2008: (a) $\mathrm{NO}_{3}^{-}$, (b) $\mathrm{NH}_{4}^{+}$, and (c) DON. Source: Vogt et al. (2012a). 

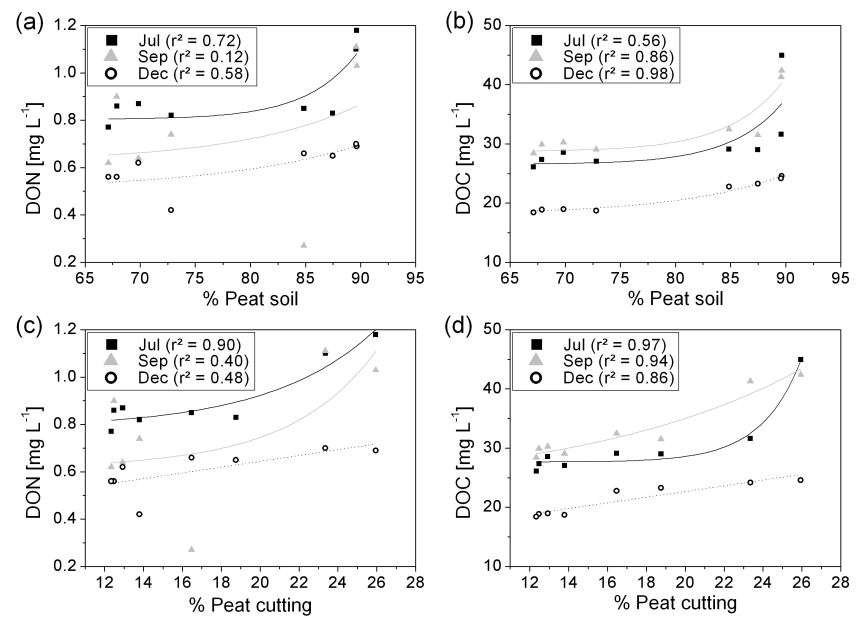

Fig. 7. Relationships between $\%$ area of peat soil (a), (b) and peat cutting (c), (d) in eight subcatchments of the Moorland catchment and spatial concentrations of DON (a), (c) and DOC (b), (d) at subcatchment outlets. The results are shown for July (black squares and line), September (grey triangles and line) and December (black circles and dotted line) and fitted as $y=A \cdot \exp (x / t)+y 0)$. Coefficients of determinations $\left(r^{2}\right)$ are given for each campaign.

DON can vary widely and differed between the catchments (Vogt et al., 2012a). In both catchments, flushing of organicrich soil water contributed to streamwater DON concentrations, however in the Grassland catchment, there were additional major sources, such as agricultural runoff.

To analyse the potential contribution of the peat cutting area to the DON as well as to the linked dissolved organic carbon (DOC) export flux of the Moorland catchment, the catchment was divided into eight subcatchments based on the drainage pattern. A regression analysis between the \% area of peat soil in these subcatchments and DON and DOC concentrations at the subcatchment outlets mostly showed a positive relationship between DOC and DON concentrations and the $\%$ area of peat soil (Fig. 7a and b). This relationship was more pronounced for DOC than DON, however, in both cases there was substantial scatter in the relationship. Other studies (e.g. Aitkenhead et al., 1999) have shown that the area of peat soil in a catchment is directly related to streamwater DOC concentration. Clark et al. (2004) found DON concentrations to be positively related to peat cover in the summer only. In this study, the relationship between DON concentrations and $\%$ area of peat soil was also strongest in July. The same regression analysis with \% peat cutting area also showed a similar positive relationship to DOC and DON concentrations (Fig. 7c and d) with a slightly stronger relationship observed between concentrations and \% peat cutting area (compared to $\%$ peat area). This is likely to be a reflection of peat cutting taking place in the areas of deepest peat in the catchment, leading to the enhanced effect shown in Fig. $7 \mathrm{c}$ and d. The areas affected by peat cutting are mostly in the upper parts of the catchment, with the effect decreasing significantly down- stream. Also, a previous study in the Moorland catchment noted that DOC concentrations were not significantly different in a large tributary originating from an area of peat cutting compared to concentrations in the main stream (Dinsmore et al., 2010). Thus, peat-rich areas (whether cut or not) are considered to be the main source of streamwater DOC and DON concentrations. However, peat cutting and associated drainage will change hydrological flow paths, which may enhance the "peat effect" on DOC and DON concentrations and contribute to higher annual fluxes because of greater runoff due to drainage. The longer term effect of peat cutting on the catchment fluvial $\mathrm{N}$ flux remains a question for further study.

\subsection{Total $\mathbf{N}$ budgets for the study catchments}

The overall nitrogen budgets for two catchments are compared in Table 3 and Fig. 8. The Moorland catchment showed a negative $\mathrm{N}$ balance of $-1.6+3.8 /-3.4$ (error) $\mathrm{kg} \mathrm{N} \mathrm{ha}^{-1} \mathrm{yr}^{-1}$, potentially indicating a small loss of $\mathrm{N}$ from catchment storage to the stream, however, within the uncertainty estimates the catchment $\mathrm{N}$ budget could also be in balance. Reynolds and Edwards (1995) stated that N accumulation is to be expected in moorland catchments. However, that study did not take stream exports of DON into account due to lack of data. The present study thus shows the importance of DON as a component of stream export: DON accounted for $81 \%$ of TDN export. The $\mathrm{N}$ loss calculated for the Moorland catchment is in agreement with an overall $\mathrm{N}$ budget of $-2.4 \mathrm{~kg} \mathrm{~N} \mathrm{ha}^{-1} \mathrm{yr}^{-1}$, derived for a field site within the Moorland catchment (Drewer et al., 2010).

Nitrogen saturation has been defined for "an ecosystem where $\mathrm{N}$ losses approximate or exceed the inputs of N" (Ågren and Bosatta, 1988; Butterbach-Bahl et al., 2011). Thus, according to our catchment soil budget approach, the Moorland catchment showed signs of $\mathrm{N}$ saturation. If the Moorland catchment is losing N, it is of interest to know whether carbon $(\mathrm{C})$ loss is also occurring. Recently, Dinsmore et al. (2010) showed the DOC downstream flux to be a significant loss within the $\mathrm{C}$ budget of the Moorland catchment, although the moorland was still found to act as a strong $\mathrm{C}$ sink, mainly due to a large $\mathrm{C}$ uptake from the atmosphere. However, in the past, the same moorland has also been found to be either $\mathrm{C}$ neutral or a small $\mathrm{C}$ source (Billett et al., 2004). The differing $C$ balances reflect large interannual variability in flux terms, particularly $\mathrm{C}$ uptake from the atmosphere, which in turn is influenced by the annual fluctuations in weather. Thus, the studied Moorland catchment may shift at an annual level from acting as a net $\mathrm{C}$ sink to a source, while at the same time releasing a significant amount of $\mathrm{C}$ from the catchment via downstream DOC export. The effects of future climate change on catchment scale $\mathrm{C}$ and $\mathrm{N}$ budgets remain highly uncertain.

The Grassland catchment had a positive $\mathrm{N}$ balance of $9.9+16.5 /-12.8$ (error) $\mathrm{kg} \mathrm{Nha}^{-1} \mathrm{yr}^{-1}$, indicating that the catchment stored $\mathrm{N}$ inputs in soil, vegetation and 
Table 3. Soil $\mathrm{N}$ budgets for the Moorland (621 ha) and the Grassland ( $895 \mathrm{ha})$ catchment with fluxes and errors shown in $\mathrm{kg} \mathrm{N} \mathrm{ha}^{-1} \mathrm{yr}^{-1}$ (see subsections under Sects. 2.3 and 2.4 for details of individual error estimations).

\begin{tabular}{|c|c|c|c|c|c|}
\hline & & \multicolumn{2}{|c|}{ Moorland catchment } & \multicolumn{2}{|c|}{ Grassland catchment } \\
\hline & & Fluxes & Error & Fluxes & Error \\
\hline \multicolumn{6}{|l|}{ Catchment $\mathrm{N}$ inputs } \\
\hline $\mathrm{NH}_{3}$ dry deposition & $\mathrm{N}_{\mathrm{NH}_{3} \text { dry dep }}$ & 2.4 & \pm 0.5 & 6.4 & \pm 1.3 \\
\hline $\mathrm{NH}_{\mathrm{X}}$ wet deposition & $\mathrm{N}_{\mathrm{NH}_{\mathrm{x}} \text { wet dep }}$ & 2.5 & \pm 0.5 & 2.6 & \pm 0.5 \\
\hline $\mathrm{NO}_{\mathrm{y}}$ deposition & $\mathrm{N}_{\mathrm{NO}_{\mathrm{y}} \text { dep }}$ & 3.3 & \pm 0.7 & 3.3 & \pm 0.7 \\
\hline Synthetic fertiliser applications & $\mathrm{N}_{\text {syn fert }}$ & 1.2 & \pm 0.1 & 9.3 & \pm 0.9 \\
\hline Organic fertiliser applications & $\mathrm{N}_{\text {org fert }}$ & 2.1 & \pm 0.6 & 16.3 & \pm 4.9 \\
\hline Grazing livestock excreta & $\mathrm{N}_{\text {excreta }}$ & 8.8 & \pm 4.4 & 26.3 & \pm 13.2 \\
\hline Biological $\mathrm{N}_{2}$ fixation & $\mathrm{N}_{\text {bio fix }}$ & 1.0 & $+3.0 /-0.7$ & 5.0 & $+15.0 /-3.5$ \\
\hline Total $\mathrm{N}$ input & & 21.3 & & 69.2 & \\
\hline \multicolumn{6}{|l|}{ Catchment $\mathrm{N}$ outputs } \\
\hline $\mathrm{NH}_{3}$ emission & $\mathrm{N}_{\mathrm{NH}_{3}}$ & 0.9 & \pm 0.2 & 4.5 & \pm 0.9 \\
\hline $\mathrm{N}_{2} \mathrm{O}$ emission & $\mathrm{N}_{\mathrm{N}_{2} \mathrm{O}}$ & 0.8 & \pm 0.4 & 2.4 & \pm 1.2 \\
\hline NO emission & $\mathrm{N}_{\mathrm{NO}}$ & 0.1 & \pm 0.0 & 0.3 & \pm 0.2 \\
\hline $\mathrm{N}_{2}$ emission & $\mathrm{N}_{\mathrm{N}_{2}}$ & 1.2 & $+2.5 /-0.6$ & 5.3 & $+10.6 /-2.6$ \\
\hline Harvested silage and hay & $\mathrm{N}_{\text {harvest }}$ & 0.7 & \pm 0.1 & 5.0 & \pm 1.0 \\
\hline Harvested grass by grazing livestock & $\mathrm{N}_{\text {grass }}{ }^{*}$ & 10.6 & \pm 5.3 & 27.4 & \pm 13.7 \\
\hline Stream export & $\mathrm{N}_{\text {stream }}$ & 8.7 & \pm 1.7 & 14.4 & \pm 2.9 \\
\hline Total $\mathrm{N}$ output & & 22.9 & & 59.3 & \\
\hline $\mathrm{N}$ balance & & -1.6 & $+3.8 /-3.4$ & +9.9 & $+16.5 /-12.8$ \\
\hline
\end{tabular}

${ }^{*} \mathrm{~N}_{\text {grass }}=\mathrm{N}_{\text {excreta }}+\mathrm{N}_{\text {animal }}-\mathrm{N}_{\text {feed }}$.

$\mathrm{N}_{\text {animal }}$ is $\mathrm{N}$ exported via wool and meat production.

$\mathrm{N}_{\text {feed }}$ is $\mathrm{N}$ imported via supplementary animal feed.

Moorland catchment: $\mathrm{N}_{\text {animal }}=2.0 \mathrm{~kg} \mathrm{Nha}^{-1} \mathrm{yr}^{-1}, \mathrm{~N}_{\text {feed }}=0.2 \mathrm{~kg} \mathrm{Nha}^{-1} \mathrm{yr}^{-1}$.

Grassland catchment: $\mathrm{N}_{\text {animal }}=5.4 \mathrm{~kg} \mathrm{Nha}^{-1} \mathrm{yr}^{-1}, \mathrm{~N}_{\text {feed }}=4.3 \mathrm{~kg} \mathrm{Nha}^{-1} \mathrm{yr}^{-1}$.

groundwater for this study year. However, as with the Moorland catchment, the error bars overlap the balance point. The stream export of the Grassland catchment represented a relatively large budget term compared with the other terms. By comparison with other European regional catchment budgets reported by Billen et al. (2011), the retention of $\mathrm{N}$ was low (Sect. 3.5).

\subsection{Uncertainties in the catchment nitrogen budgets}

For both catchments, the budget terms with the largest error bars were the outputs through grazed grass $\left(\mathrm{N}_{\text {grass }}\right)$ and the input through grazing excreta $\left(\mathrm{N}_{\text {excreta }}\right)$, as noted above. However, as those terms are interdependent and it is the difference between them that contributes to the overall uncertainty of the $\mathrm{N}$ balance calculation, the net error is smaller than the individual errors. In the Moorland catchment, the budget terms contributing the most to the uncertainty of the $\mathrm{N}$ balance were biological $\mathrm{N}_{2}$ fixation, stream export and $\mathrm{N}_{2}$ emissions. In the Grassland catchment, the most important terms contributing to uncertainty were biological $\mathrm{N}_{2}$ fixation and $\mathrm{N}_{2}$ emissions, followed by applied organic fertiliser and stream export. The overall uncertainty of the $\mathrm{N}$ balances were large, the Moorland catchment balance being $-1.6 \mathrm{~kg} \mathrm{~N} \mathrm{ha}^{-1} \mathrm{yr}^{-1}$ with estimated upper and lower balance values of +2.2 and $-5.0 \mathrm{~kg} \mathrm{Nha}^{-1} \mathrm{yr}^{-1}$, accounting for uncertainties. Similarly, the upper and lower estimates of the Grassland catchment of $+9.9 \mathrm{~kg} \mathrm{~N} \mathrm{ha}^{-1} \mathrm{yr}^{-1}$ range between +26.4 and $-2.9 \mathrm{~kg} \mathrm{~N} \mathrm{ha}^{-1} \mathrm{yr}^{-1}$. Hence, although we present a detailed budget analysis, the uncertainties remain inherently large.

There are several terms still missing from the $\mathrm{N}$ budget calculation, which may add further uncertainty to the current balance estimate. In particular, atmospheric deposition of gaseous and particulate organic $\mathrm{N}$ compounds were not quantified nor estimated due to lack of information, although organic deposition may be an important input (Cape et al., 2004; Neff et al., 2002). Moreover, fluvial N export through particulate organic $\mathrm{N}(\mathrm{PON})$ was not measured, although the PON flux is likely to be insignificant compared to the DON flux, as was the POC flux to the DOC flux measured in the Moorland catchment by Dinsmore et al. (2010).

Although our study was detailed, it was carried out over a relatively short time period (one year), which may affect some of the conclusions drawn from the data. In particular, stream export fluxes are known to vary year-on-year due to 

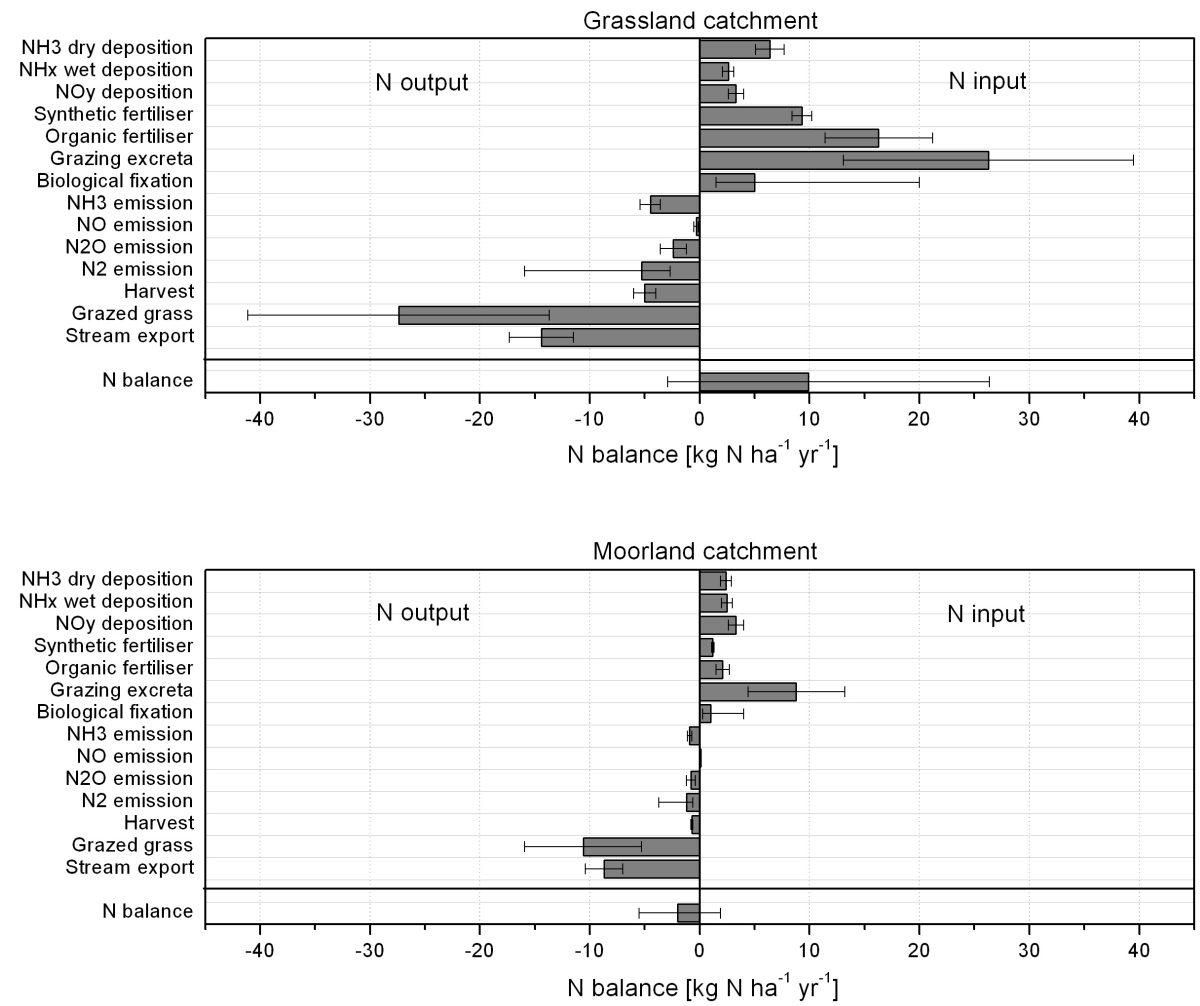

Fig. 8. Catchment soil $\mathrm{N}$ budgets for the Grassland catchment (top) and the Moorland catchment (bottom). Inputs and outputs are shown as positive and negative $\mathrm{N}$ exchanges $\left(\mathrm{kg} \mathrm{N} \mathrm{ha}^{-1} \mathrm{yr}^{-1}\right)$ with the overall $\mathrm{N}$ balance shown at the bottom. Error bars represent the estimated uncertainty for the individual budget terms (see subsections under Sects. 2.3 and 2.4) with the N balance error calculated accordingly (see Sect. 2.2).

climatic fluctuations (Gascuel-Odoux et al., 2010). Further study on the $\mathrm{N}$ budgets of these catchments is needed to clarify the role of annual variation. Another source of uncertainty is the assumption that land use and $\mathrm{N}$ input remain approximately constant with time, allowing the balancing of $\mathrm{N}$ exported through the aqueous system with the $\mathrm{N}$ exchange at the surface.

\subsection{Comparison with a regional catchment $\mathrm{N}$ budget approach}

Regional scale catchment $\mathrm{N}$ budgets have been estimated for many European catchments (Billen et al., 2011). The approach combines a calculation of the net anthropogenic input of reactive nitrogen (NANI, Howarth et al., 1996; Swaney et al., 2012) to the catchment with data on atmospheric $\mathrm{NO}_{\mathrm{y}}$ deposition, crop $\mathrm{N}$ fixation, fertiliser use and import of food and feed. This is a simple approach which can be applied to large regions, but does not account for processes like $\mathrm{NH}_{3}$ volatilisation or soil denitrification. In European regional catchments, NANI ranges between 0 and $84 \mathrm{~kg} \mathrm{Nha}^{-1} \mathrm{yr}^{-1}$ (mean: $37 \mathrm{~kg} \mathrm{Nha}^{-1} \mathrm{yr}^{-1}$ ) (Billen et al., 2011). The relative difference of NANI to the stream export of total $\mathrm{N}$ $(\mathrm{TN}=\mathrm{DIN}+\mathrm{DON}+\mathrm{PON})$ is then associated with catch- ment $\mathrm{N}$ retention. Catchment retention refers to the amount of $\mathrm{N}$ which is either stored in soils and groundwater or lost through emissions to the atmosphere. In regional European catchments, catchment $\mathrm{N}$ retention varies between $50 \%$ and $90 \%$ of NANI (mean: $82 \%$ ) (Billen et al., 2011). There is some evidence that the fraction of NANI exported by the stream is larger in catchments with high discharges (Howarth et al., 2006).

These regional budget calculations differ substantially to the one presented here, (e.g. coarser scale data, no $\mathrm{NH}_{\mathrm{x}}$ deposition, no land emissions, no organic fertiliser applications); however, the catchment retention calculated as the percentage of $\mathrm{N}$ input which is stored or emitted using our budget terms for the landscape scale may emphasise the differences of regional and landscape scale $\mathrm{N}$ budgets. Thus, the agricultural surplus as the difference between $\mathrm{N}$ inputs to catchment soils and outputs via harvested or grazed crops (Lassaletta et al., 2012) was calculated (see Sect. 2.2 for budget term definitions):

$$
\begin{aligned}
& \text { agricultural surplus }=\mathrm{N}_{\mathrm{NH}_{3} \text { dry dep }}+\mathrm{N}_{\mathrm{NH}_{\mathrm{x}} \text { wet dep }}+\mathrm{N}_{\mathrm{NO}_{\mathrm{y}} \text { dep }} \\
& +\mathrm{N}_{\text {syn fert }}+\mathrm{N}_{\text {org fert }}+\mathrm{N}_{\text {excreta }}+\mathrm{N}_{\text {bio fix }}-\mathrm{N}_{\text {harvest }}-\mathrm{N}_{\text {grass }} .
\end{aligned}
$$


The agricultural surplus differs to the budget calculation of Eq. (1) in that the land emissions and stream export are not taken into account. Atmospheric emissions were excluded in order to calculate what hydrologists term "catchment retention", i.e. the fraction that is not exported in streamwater (which includes $\mathrm{N}$ losses to the atmosphere). The agricultural surplus was calculated to be $10.0 \mathrm{~kg} \mathrm{Nha}^{-1} \mathrm{yr}^{-1}$ for the Moorland and $36.8 \mathrm{~kg} \mathrm{~N} \mathrm{ha}^{-1} \mathrm{yr}^{-1}$ for the Grassland catchment. The stream $\mathrm{N}$ export (not including PON) represented, therefore, $87 \%$ of agricultural surplus in the Moorland, compared with $39 \%$ in the Grassland catchment. This implies a catchment retention of $13 \%$ in the Moorland and $61 \%$ in the Grassland catchment. These values are low, particularly the retention of the Moorland catchment, compared to the catchment retention calculated at regional scale in Europe with an average of $82 \%$ (Billen et al., 2011). Reasons for the difference between these two budget approaches are likely to be the finer scale resolution of our landscape scale study allowing, firstly, for more accurate quantification of the $\mathrm{N}$ budget terms and secondly, for the calculation of more budget terms to account for the $\mathrm{N}$ input related to catchment soils.

Expressed in terms of our comprehensive landscape $\mathrm{N}$ budgets, the actual "net nitrogen retention" ([all $\mathrm{N}_{\text {input }}$ - all $\left.\mathrm{N}_{\text {output }}\right] /$ all $\mathrm{N}_{\text {input }} \cdot 100$ ) would be $+14.3 \%$ and $-7.6 \%$ for the Grassland and Moorland catchments, respectively.

\section{Conclusions}

Nitrogen budgets for two adjacent catchments with contrasting land use within a single landscape unit were calculated taking into account all agricultural activity and each of the important gaseous and aqueous inputs and outputs. This allowed a detailed analysis of catchment inputs and outputs at a much higher spatial resolution than before. Within the errors associated with components of the $\mathrm{N}$ budget, the best estimates suggested a tendency for the Grassland catchment to gain nitrogen $\left(+10[-3,+26] \mathrm{kg} \mathrm{N} \mathrm{ha}^{-1} \mathrm{yr}^{-1}\right)$ and for the Moorland catchment to lose nitrogen $\left(-2[-5,+2] \mathrm{kg} \mathrm{Nha}^{-1} \mathrm{yr}^{-1}\right)$. The key uncertainties of our $\mathrm{N}$ budget approach were biological $\mathrm{N}_{2}$ fixation, $\mathrm{N}_{2}$ emissions and stream $\mathrm{N}$ export. This emphasises, firstly the need for more studies addressing the quantification of $\mathrm{N}_{2}$ exchange and, secondly the importance of estimating downstream fluxes accurately when compiling $\mathrm{N}$ budgets. Even the well-established downstream fluxes of this study (including DON) introduce a key uncertainty to the budget calculations as the stream exports represent large budget terms.

The $\mathrm{N}$ budgets of the two study catchments indicate that both catchments have a limited capacity to store nitrogen within soils, vegetation and groundwater. This important finding contrasts with regional scale estimates. The "catch- ment retention" of $\mathrm{N}$, calculated as the percentage of $\mathrm{N}$ input which is not lost in streamwater (i.e. stored within the catchment or emitted to the atmosphere), amounted to $13 \%$ in the Moorland and $61 \%$ in the Grassland catchment. These values are relatively small compared with estimated catchment retentions in European catchments at the regional scale, ranging from $50 \%$ to $90 \%$ (Billen et al., 2011). Whereas larger, regional scale approaches to estimating catchment input/output may be important for a global overview, these approaches tend to hide the landscape scale $\mathrm{N}$ dynamics and thus the local scale environmental impact of human activities.

This work on compiling landscape scale nitrogen budgets represents the beginning of a better understanding of the anthropogenic impact via agricultural activities on European landscapes. Within the NitroEurope Integrated Project (Sutton et al., 2007), the outcomes of this study are being further analysed in the context of nitrogen fluxes and budgets quantified in different landscapes across Europe, with differing agricultural land use and climate. This will provide a quantitative comparison of the key $\mathrm{N}$ fluxes and their spatial dynamics across European landscapes, providing a basis to tune locally optimised management strategies.

Acknowledgements. This work was funded by the NitroEurope Integrated Project (www.nitroeurope.eu), supported by the European Commission, 6th Framework Programme, the Centre for Ecology \& Hydrology, Scotland's Rural College, together with complementary inputs from the UK Department of Food and Rural Affairs (Defra), COST 729 and the NinE network of the European Science Foundation. The authors are grateful for the cooperation of all farmers in the study landscape, in particular the poultry farm, for detailed management data.

Edited by: G. Billen

\section{References}

Ågren, G. I. and Bosatta, E.: Nitrogen saturation of terrestrial ecosystems, Environ. Pollut., 54, 185-197, 1988.

Aitkenhead, J. A., Hope, D., and Billett, M. F.: The relationship between dissolved organic carbon in stream water and soil organic carbon pools at different spatial scales, Hydrol. Process., 13, 1289-1302, 1999.

Ammann, C., Spirig, C., Leifeld, J., and Neftel, A.: Assessment of the nitrogen and carbon budget of two managed temperate grassland fields, Agr. Ecosyst. Environ., 133, 150-162, 2009.

Asman, W. A. H., Sutton, M. A., and Schjørring, J. K.: Ammonia: emission, atmospheric transport and deposition, New Phytol., 139, 27-48, 1998.

Billen, G., Thieu, V., Garnier, J., and Silvestre, M.: Modelling the $\mathrm{N}$ cascade in regional watersheds: The case study of the Seine, Somme and Scheldt rivers, Agr. Ecosyst. Environ., 133, 234246, 2009.

Billen, G., Silvestre, M., Grizzetti, B., Leip, A., Garnier, J., Voß, M., Howarth, R., Bouraoui, F., Lepistö, A., Kortelainen, P., Johnes, 
P., Curtis, C., Humborg, C., Smedberg, E., Kaste, O., Ganeshram, R., Beusen, A., and Lancelot, C.: Nitrogen flows from European regional watersheds to coastal marine waters, in: The European nitrogen assessment - Sources, effects and policy perspectives, edited by: Sutton, M. A., Howard, C. M., Erisman, J. W., Billen, G., Bleeker, A., Grennfelt, P., Van Grinsven, H., and Grizzetti, B., Cambridge University Press, Cambridge, 271-297, 2011.

Billett, M. F., Palmer, S. M., Hope, D., Deacon, C., StoretonWest, R., Hargreaves, K. J., Flechard, C., and Fowler, D.: Linking land-atmosphere-stream carbon fluxes in a lowland peatland system, Global Biogeochem. Cy., 18, GB1024, doi:10.1029/2003GB002058, 2004.

Bouwman, A. F., Boumans, L. J. M., and Batjes N. H.: Modeling global annual $\mathrm{N}_{2} \mathrm{O}$ and $\mathrm{NO}$ emissions from fertilized fields, Global Biogeochem. Cy., 16, 1080, doi:10.1029/2001GB001812, 2002.

Bouwman, A. F., Van Drecht, G., and Van der Hoek, K. W.: Global and regional surface nitrogen balances in intensive agricultural production systems for the period 1970-2030, Pedosphere, 15, 137-155, 2005.

Butterbach-Bahl, K., Gundersen, P., Ambus, P., Augustin, J., Beier, C., Boeckx, P., Dannenmann, M., Sanchez Gimeno, B., Ibrom, A., Kiese, R., Kitzler, B., Rees, R. M., Smith, K. A., Stevens, C., Vesala, T., and Zechmeister-Boltenstein, S.: Nitrogen processes in terrestrial ecosystems, in: The European nitrogen assessment - Sources, effects and policy perspectives, edited by: Sutton, M. A., Howard, C. M., Erisman, J. W., Billen, G., Bleeker, A., Grennfelt, P., Van Grinsven, H., and Grizzetti, B., Cambridge University Press, Cambridge, 99-125, 2011.

Cape, J. N., Anderson, M., Rowland, A. P., and Wilson, D., Organic nitrogen in precipitation across the United Kingdom, Water Air Soil Poll., 4, 25-35, 2004.

Cellier, P., Durand, P., Hutchings, N., Dragosits, U., Theobald, M. R., Drouet, J.-L., Oenema, O., Bleeker, A., Breuer, L., Dalgaard, T., Duretz, S., Kros, J., Loubet, B., Olesen, J. E., Merot, P., Viaud, V., de Vries, W., and Sutton, M. A.: Nitrogen flows and fate in rural landscapes, in: The European nitrogen assessment - Sources, effects and policy perspectives, edited by: Sutton, M. A., Howard, C. M., Erisman, J. W., Billen, G., Bleeker, A., Grennfelt, P., Van Grinsven, H., and Grizzetti, B., Cambridge University Press, Cambridge, 229-248, 2011.

Clark, M. J., Cresser, M. S., Smart, R., Chapman, P. J., and Edwards, A. C.: The influence of catchment characteristics on the seasonality of carbon and nitrogen species concentrations in upland rivers of Northern Scotland, Biogeochemistry, 68, 1-19, 2004.

Dalgaard, T., Hutchings, N., Dragosits, U., Olesen, J. E., Kjeldsen, C., Drouet, J. L., and Cellier, P.: Effects of farm heterogeneity and methods for upscaling on modelled nitrogen losses in agricultural landscapes, Environ. Pollut., 159, 3183-3192, 2011.

De Klein, C., Novoa, R. S. A., Ogle, S., Smith, K. A., Rochette, P., Wirth, T. C., McConkey, B. G., Mosier, A., Rypdal, K., Walsh, M., and Williams, S. A.: $\mathrm{N}_{2} \mathrm{O}$ emissions from managed soils, and $\mathrm{CO}_{2}$ emissions from lime and urea application, in: IPCC Guidelines for National Greenhouse Gas Inventories, edited by: Eggleston, S., Buendia, L., Miwa, K., Ngara, T., and Tanabe, K., Institute for Global Environmental Strategies (IGES), Hayama, Japan, 2009.

de Vries, W., Cellier, P., Erisman, J. W., and Sutton, M. A.: Assessment of nitrogen fluxes to air and water from site scale to con- tinental scale: An overview, Environ. Pollut., 159, 3143-3148, 2011a.

de Vries, W., Leip, A., Reinds, G. J., Kros, J., Lesschen, J. P., and Bouwman, A. F.: Comparison of land nitrogen budgets for European agriculture by various modeling approaches, Environ. Pollut., 159, 3254-3268, 2011b.

Defra (Department for Environmental Food and Rural Affairs): Fertiliser Manual (RB209), 8th Edn., TSO (The Stationary Office), Norwich, UK, 2010.

Defra (Department for Environmental Food and Rural Affairs): www.defra.gov.uk/food-farm/land-manage/ nitrates-watercourses/nitrates/ (last access: 25 January 2012), 2012.

DeLuca, T. H., Zackrisson, O., Gundale, M. J., and Nilsson, M. C.: Ecosystem feedbacks and nitrogen fixation in boreal forests, Science, 320, 1181-1181, 2008.

Dinsmore, K. J., Billett, M. F., Skiba, U. M., Rees, R. M., Drewer, J., and Helfter, C., Role of the aquatic pathway in the carbon and greenhouse gas budgets of a peatland catchment, Glob. Change Biol., 16, 2750-2762, 2010.

Dore, A. J., Vieno, M., Tang, Y. S., Dragosits, U., Dosio, A., Weston, K. J., and Sutton, M. A.: Modelling the atmospheric transport and deposition of sulphur and nitrogen over the United Kingdom and assessment of the influence of $\mathrm{SO}_{2}$ emissions from international shipping, Atmos. Environ., 41, 2355-2367, 2007.

Dore, A. J., Kryza, M., Hall, J. R., Hallsworth, S., Keller, V. J. D., Vieno, M., and Sutton, M. A.: The influence of model grid resolution on estimation of national scale nitrogen deposition and exceedance of critical loads, Biogeosciences, 9, 1597-1609, doi:10.5194/bg-9-1597-2012, 2012.

Drewer, J., Lohila, A., Aurela, M., Laurila, T., Minkkinen, K., Penttila, T., Dinsmore, K. J., McKenzie, R. M., Helfter, C., Flechard, C., Sutton, M. A., and Skiba, U. M.: Comparison of greenhouse gas fluxes and nitrogen budgets from an ombotrophic bog in Scotland and a minerotrophic sedge fen in Finland, Eur. J. Soil Sci., 61, 640-650, 2010.

Duyzer, J.: Dry deposition of ammonia and ammonium aerosols over heathland, J. Geophys. Res., 99, 18757-18763, 1994.

Flindt, R.: Biologie in Zahlen, Eine Datensammlung in Tabellen mit über 10.000 Einzelwerten, Spektrum Akademischer Verlag Gustav Fischer, Stuttgart, Germany, 296 pp., 2003.

Galloway, J. N., Dentener, F. J., Capone, D. G., Boyer, E. W., Howarth, R. W., Seitzinger, S. P., Asner, G. P., Cleveland, C. C., Green, P. A., Holland, E. A., Karl, D. M., Michaels, A. F., Porter, J. H., Townsend, A. R., and Vorosmarty, C. J.: Nitrogen cycles: past, present, and future, Biogeochemistry, 70, 153-226, 2004.

Galloway, J. N., Townsend, A. R., Erisman, J. W., Bekunda, M., Cai, Z. C., Freney, J. R., Martinelli, L. A., Seitzinger, S. P., and Sutton, M. A.: Transformation of the nitrogen cycle: Recent trends, questions, and potential solutions, Science, 320, 889-892, 2008.

Gascuel-Odoux, C., Aurousseau, P., Durand, P., Ruiz, L., and Molenat J.: The role of climate on inter-annual variation in stream nitrate fluxes and concentrations, Sci. Total Environ., 408, 56575666, 2010.

Hallsworth, S., Dore, A. J., Bealey, W. I., Dragosits, U., Vieno, M., Hellsten, S., Tang, Y. S., and Sutton, M. A.: The role of indicator choice in quantifying the threat of atmospheric ammonia to the 'Natura 2000' network, Environ. Sci. Policy, 13, 671-687, 2010. 
Hertel, O., Reis, S., Skjøth, C. A., Bleeker, A., Harrison, R., Cape, J. N., Fowler, D., Skiba, U., Simpson, D., Jickells, T., Baker, A., Kulmala, M., Gyldenkærne, S., Sørensen, L. L., and Erisman, J. W.: Nitrogen processes in the atmosphere, in: The European nitrogen assessment - Sources, effects and policy perspectives, edited by: Sutton, M. A., Howard, C. M., Erisman, J. W., Billen, G., Bleeker, A., Grennfelt, P., Van Grinsven, H., and Grizzetti, B., Cambridge University Press, Cambridge, 177-207, 2011.

Hill, J.: Applications of computational modelling to ammonia dispersion from agricultural sources, $\mathrm{PhD}$, Imperial College, Centre for Environmental Technology, University of London, London, UK, 1998.

Hofstra, N. and Bouwman, A. F.: Denitrification in agricultural soils: Summarizing published data and estimating global annual rates, Nutr. Cycl. Agroecosys., 72, 267-278, 2005.

Howarth, R. W., Billen, G., Swaney, D., Townsend, A., Jaworski, N., Lajtha, K., Downing, J. A., Elmgren, R., Caraco, N., Jordan, T., Berendse, F., Freney, J., Kudeyarov, V., Murdoch, P., and Zhu, Z. L.: Regional nitrogen budgets and riverine N\&P fluxes for the drainages to the North Atlantic Ocean: Natural and human influences, Biogeochemistry, 35, 75-139, 1996.

Howarth, R. W., Swaney D. P., Boyer, E. W., Marino, R., Jaworski, N., and Goodale, C.: The influence of climate on average nitrogen export from large watersheds in the Northeastern United States, Biogeochemistry 79, 163-186, 2006.

Klemedtsson, L., von Arnold, K., Weslien, P., and Gundersen, P.: Soil CN ratio as a scalar parameter to predict nitrous oxide emissions, Glob. Change Biol., 11, 1142-1147, 2005.

Kros, J., Frumau, K. F. A., Hensen, A. and de Vries, W.: Integrated analysis of the effects of agricultural management on nitrogen fluxes at landscape scale, Environ. Pollut., 159, 31713182, 2011.

Kros, J., Heuvelink, G. B. M., Reinds, G. J., Lesschen, J. P., Ioannidi, V., and De Vries, W.: Uncertainties in model predictions of nitrogen fluxes from agro-ecosystems in Europe, Biogeosciences, 9, 4573-4588, doi:10.5194/bg-9-4573-2012, 2012.

Lassaletta, L., Romero, E., Billen, G., Garnier, J., García-Gómez, H., and Rovira, J. V.: Spatialized N budgets in a large agricultural Mediterranean watershed: high loading and low transfer, Biogeosciences, 9, 57-70, doi:10.5194/bg-9-57-2012, 2012.

Leip, A., Britz, W., Weiss, F., and de Vries, W.: Farm, land, and soil nitrogen budgets for agriculture in Europe calculated with CAPRI, Environ. Pollut., 159, 3243-3253, 2011.

Lesschen, J. P., Velthof, G. L., de Vries, W., and Kros, J.: Differentiation of nitrous oxide emission factors for agricultural soils, Environ. Pollut., 159, 3215-3222, 2011.

Limmer, C. and Drake, H. L.: Non-symbiotic $\mathrm{N}_{2}$-fixation in acidic and $\mathrm{pH}$-neutral forest soils: Aerobic and anaerobic differentials, Soil Biol. Biochem., 28, 177-183, 1996.

Loubet, B., Asman, W. A. H., Theobald, M. R., Hertel, O., Tang, Y. S., Robin, P., Hassouna, M., Dammgen, U., Genermont, S., Cellier, P., and Sutton, M. A.: Ammonia deposition near hot spots: Processes, models and monitoring methods, in: Atmospheric ammonia - Detecting emission changes and environmental impacts, edited by: Sutton, M. A., Reis, S., and Baker, S. M. H., Springer, Dordrecht, 205-267, 2009.

McDowell, W. H. and Asbury, C. E.: Export of carbon, nitrogen, and major ions from 3 tropical montane watersheds, Limnol. Oceanogr., 39, 111-125, 1994.
McGlade, J. and Vidic, S.: EMEP/EEA air pollutant emission inventory guidebook 2009: Technical guidance to prepare national emission inventories, Technical report 9/2009, EEA, Copenhagen, Denmark, 2009.

Misselbrook, T. H., Chadwick, D. R., Gilhespy, S. L., Chambers, B. J., Smith, K. A., Williams, J., and Dragosits U.: Inventory of ammonia emissions from UK agriculture 2008 (Defra Contract AC0112), North Wyke Research, Devon, UK, 2009.

Møller, J., Thøgersen, R., Helleshøj, M. E., Weisbjerg, M. R., Søegaard, K., and Hvelplund, T.: Foddermiddeltabel 2005, Rapport nr. 112, Dansk Kvæg, 2005.

Neff, J. C., Holland, E. A., Dentener, F. J., McDowell, W. H., and Russell, K. M.: The origin, composition and rates of organic nitrogen deposition: A missing piece of the nitrogen cycle?, Biogeochemistry, 57, 99-136, 2002.

Oenema, O., Kros, H., and de Vries, W.: Approaches and uncertainties in nutrient budgets: implications for nutrient management and environmental policies, Eur. J. Agr., 20, 3-16, 2003.

Reynolds, B. and Edwards, A.: Factors influencing dissolved nitrogen concentrations and loadings in upland streams of the UK, Agr. Water Manage., 27, 181-202, 1995.

Roche, J.: The international wool trade. Woodhead Publishing Limited, Cambridge, UK, 231 pp., 1995.

Schröder, J. J., Aarts, H. F. M., ten Berge, H. F. M., van Keulen, H., and Neeteson, J. J.: An evaluation of whole-farm nitrogen balances and related indices for efficient nitrogen use, Eur. J. Agr., 20, 33-44, 2003.

Seitzinger, S. P., Harrison, J. A., Dumont, E., Beusen, A. H. W., and Bouwman, A. F.: Sources and delivery of carbon, nitrogen, and phosphorus to the coastal zone: An overview of Global Nutrient Export from Watersheds (NEWS) models and their application, Global Biogeochem. Cy., 19, GB4S01, doi:10.1029/2005GB002606, 2005.

Sutton, M. A., Milford, C., Dragosits, U., Place, C. J., Singles, R. J., Smith, R. I., Pitcairn, C. E. R., Fowler, D., Hill, J., ApSimon, H. M., Ross, C., Hill, R., Jarvis, S. C., Pain, B. F., Phillips, V. C., Harrison, R., Moss, D., Webb, J., Espenhahn, S. E., Lee, D. S., Hornung, M., Ullyett, J., Bull, K. R., Emmett, B. A., Lowe, J., and Wyers, G. P.: Dispersion, deposition and impacts of atmospheric ammonia: quantifying local budgets and spatial variability, Environ. Pollut. 102, 349-361, 1998.

Sutton, M. A., Nemitz, E., Erisman, J. W., Beier, C., Bahl, K. B., Cellier, P., de Vries, W., Cotrufo, F., Skiba, U., Di Marco, C., Jones, S., Laville, P., Soussana, J. F., Loubet, B., Twigg, M., Famulari, D., Whitehead, J., Gallagher, M. W., Neftel, A., Flechard, C. R., Herrmann, B., Calanca, P. L., Schjoerring, J. K., Daemmgen, U., Horvath, L., Tang, Y. S., Emmett, B. A., Tietema, A., Penuelas, J., Kesik, M., Brueggemann, N., Pilegaard, K., Vesala, T., Campbell, C. L., Olesen, J. E., Dragosits, U., Theobald, M. R., Levy, P., Mobbs, D. C., Milne, R., Viovy, N., Vuichard, N., Smith, J. U., Smith, P., Bergamaschi, P., Fowler, D., and Reis, S.: Challenges in quantifying biosphere-atmosphere exchange of nitrogen species. Environ. Pollut., 150, 125-139, 2007.

Swaney, D. P., Hong, B., Ti, C., Howarth, R. W., and Humborg, C.: Net anthropogenic nitrogen inputs to watersheds and riverine $\mathrm{N}$ export to coastal waters: a brief overview, Current Opinion in Environmental Sustainability, 4, 203-211, 2012.

Tang, Y. S., Cape, J. N., and Sutton, M. A.: Development and types of passive samplers for monitoring atmospheric $\mathrm{NO}_{2}$ and $\mathrm{NH}_{3}$ 
concentrations, The Scientific World Journal, 1, 513-529, 2001.

Tang, Y. S., Simmons, I., van Dijk, N., Di Marco, C., Nemitz, E., Dammgen, U., Gilke, K., Djuricic, V., Vidic, S., Gliha, Z., Borovecki, D., Mitosinkova, M., Hanssen, J. E., Uggerud, T. H., Sanz, M. J., Sanz, P., Chorda, J. V., Flechard, C. R., Fauvel, Y., Ferm, M., Perrino, C., and Sutton, M. A., European scale application of atmospheric reactive nitrogen measurements in a low-cost approach to infer dry deposition fluxes, Agr. Ecosyst. Environ., 133, 183-195, 2009.

Turner, M. G. and Gardner, R. H.: Quantitative methods in landscape ecology: the analysis and interpretation of landscape heterogeneity, Springer, New York, 571 pp., 1994.

Vitousek, P. M., Aber, J. D., Howarth, R. W., Likens, G. E., Matson, P. A., Schindler, D. W., Schlesinger, W. H., and Tilman, D. G.: Human alteration of the global nitrogen cycle: Sources and consequences, Ecol. Appl., 7, 737-750, 1997.
Vogt, E., Braban, C. F., Dragosits, U., Durand, P., Theobald, M. R., Sutton, M. A., Rees, R. M., McDonald, C., Murray, S., and Billett, M. F.: Effect of catchment land use on fluxes and concentrations of organic and inorganic nitrogen in streams, in preparation, 2012a.

Vogt, E., Dragosits, U., Braban, C. F., Theobald, M. R., Dore, A. J., Van Dijk, N., Tang, Y. S., McDonald, C., Murray, S., Rees, R. M., and Sutton, M. A.: Heterogeneity of atmospheric ammonia at the landscape scale and its consequences for environmental impact assessment, Environ. Pollut., in review, 2012b.

Waughman, G. J. and Bellamy, D. J., Nitrogen-fixation and the nitrogen-balance in peatland ecosystems, Ecology, 61, 11851198, 1980. 